\title{
The Original Meaning of the Commerce Clause
}

\author{
Randy E. Barnett $\dagger$
}

The U.S. Supreme Court, in recent cases, has attempted to define limits on the Congress's power to regulate commerce among the several states. While Justice Thomas has maintained that the original meaning of "commerce" was limited to the "trade and exchange" of goods and transportation for this purpose, some have argued that he is mistaken and that "commerce" originally included any "gainful activity." Having examined every appearance of the word "commerce" in the records of the Constitutional Convention, the ratification debates, and the Federalist Papers, Professor Barnett finds no surviving example of this term being used in this broader sense. In every appearance where the context suggests a specific usage, the narrow meaning is always employed. Moreover, originalist evidence of the meaning of "among the several States" and "To regulate" also supports a narrow reading of the Commerce Clause. "Among the several States" meant between persons of one state and another; and "To regulate" generally meant "to make regular"-that is, to specify how an activity may be transacted - when applied to domestic commerce, but when applied to foreign trade also included the power to make "prohibitory regulations." In sum, according to the original meaning of the Commerce Clause, Congress has power to specify rules to govern the manner by which people may exchange or trade goods from one state to another, to remove obstructions to domestic trade erected by states, and to both regulate and restrict the flow of goods to and from other nations (and the Indian tribes) for the purpose of promoting the domestic economy and foreign trade.

In United States $v$ Lopez, for the first time in sixty years, the Supreme Court of the United States held a statute to be unconstitutional because it exceeded the powers of Congress under the Commerce Clause. ${ }^{2}$ In his concurring opinion, Justice Thomas offered a critique of contemporary Commerce Clause doctrine-based on the original meaning of the clause - that went well beyond the majority opinion. According to Justice Thomas, "[a]t the time the original Constitution was ratified, 'commerce' consisted of selling, buying, and bartering, as well as transporting for these purposes." $\mathrm{He}$ also cited the etymology of the word, which literally means "with merchandise." He then noted

$\dagger$ Austin B. Fietcher Professor, Boston University School of Law (<rbarnett@bu.edu>). I wish to thank Richard Epstein, Olivier Moreteau, David Snyder, Nancy Staudt, my colleagues Jack Beermann, Oona Hathaway, Steve Marks, Mike Meurer, and especially Susan Koniak for their extraordinarily helpful comments and suggestions.

1514 US 549 (1995).

2 Id at 552.

3 Id at 585. Justice Thomas cited: Samuel Johnson, 1 A Dictionary of the English Language 361 (W. Strahan 4th ed 1773) (defining commerce as "Intercour[s]e; exchange of one thing for another; interchange of any thing; trade; traffick"); Nathan Bailey, An Universal Etymological English Dictionary (Neill 26th ed 1789) ("trade or traffic"); T. Sheridan, A Complete Dictionary of the English Language 585-86 (W. Young, Mills and Son 6th ed 1796) ("Exchange of one thing for another; trade, traffick").

4 Justice Thomas relied on the Oxford English Dictionary for the etymology of the word "commerce." 514 US at 585-86. See 3 Oxford English Dictionary 552 (2d ed 1989) (com - "with"; merci-"merchandise"). 
that "when Federalists and Anti-Federalists discussed the Commerce Clause during the ratification period, they often used trade (in its selling/bartering sense) and commerce interchangeably." The term "commerce," according to Justice Thomas, "was used in contradistinction to productive activities such as manufacturing and agriculture."

In his opinion, Justice Thomas endorsed the view of the meaning of "commerce" that the Supreme Court of the Progressive Era used to strike down various regulations of economic activity. In cases such as United States v E.C. Knight Co, the Court distinguished "commerce" from manufacturing or agriculture, and held that the regulation of either manufacturing or agriculture exceeded the powers of Congress under the clause."

Referring to "what legal historians with proper derision call 'law office history," Judge Richard Posner cited Justice Thomas's concurrence as an example of "highly debatable historical excursus by originalist judges." "Justice Thomas's conception of the original meaning of the Commerce Clause has also been challenged in a lengthy article by Professors Grant Nelson and Robert Pushaw, Jr." They examine "the original meaning, intent, and understanding" of the Commerce Clause and reach the conclusion that commerce originally referred to any "gainful activity." As such it would embrace all manufacturing and agriculture in addition to trade and exchange.

5514 US at 586. Thomas cited: Federalist 4 (Jay), in Jacob E. Cooke, ed, The Federalist Papers 22 (Wesleyan 1961) (asserting that countries will cultivate our friendship when our "trade" is prudently regulated by the federal government); Federalist 7 (Hamilton), in Cooke, ed, The Federalist Papers at 39-40 (discussing "competitions of commerce" between states resulting from state "regulations of trade"); Federalist 40 (Madison), in Cooke, ed, The Federalist Papers at 262 (asserting that it was an "acknowledged object of the Convention ... that the regulation of trade should be submitted to the general government"); Richard Henry Lee, Letters of a Federal Farmer No. 5, in Paul Leicester Ford, ed, Pamphlets on the Constitution of the United States 1787. 88 318, 319 (1888); Melancton Smith, An Address to the People of the State of New-York, in Ford, ed, Pamphlets on the Constitution 88, 107.

6514 US at 586-87. Thomas cited in support of this Alexander Hamilton in The Federalist Papers and two instances of such usage in the ratification conventions.

7 Id at 599 ("If anything, the 'wrong turn' was the Court's dramatic departure in the 1930's from a century and a half of precedent.").

8156 US 1 (1895).

9 Id at 12 ("Commerce succeeds to manufacture, and is not a part of it.").

10 Richard A. Posner, Past-Dependency, Pragmatism, and Critique of History in Adjudication and Legal Scholarship, 67 U Chi L Rev 573, 595 \& n 56 (2000).

11 Grant S. Nelson and Robert J. Pushaw, Jr., Rethinking the Commerce Clause: Applying First Principles to Uphold Federal Commercial Regulations but Preserve State Control over Social Issues, 85 Iowa L Rev 1 (1999).

12 Id at 13.

13 Id at 13-20. 
In their article, Nelson and Pushaw rely "heavily" earlier works of scholarship that had challenged the Progressive Era Court's limited conception of commerce: The Power to Govern by Walton Hamilton and Douglass Adair, ${ }^{15}$ and Politics and the Constitution in the History of the United States by William Crosskey. ${ }^{16}$ Though recognizing the many well-documented deficiencies in Crosskey's work, they state their agreement "with those scholars who have found Crosskey's evidence persuasive in establishing the meaning of 'commerce,' but not his other claims (such as the supposed creation of a national government with complete legislative authority)."17

Nelson and Pushaw chide other modern scholars, such as Albert Abel, ${ }^{18}$ Richard Epstein, ${ }^{19}$ and Raoul Berger, ${ }^{20}$ who have endorsed the narrow view - as well as Justice Thomas for relying upon them - for ignoring the "massive eighteenth-century linguistic and historical evidence demonstrating that the Commerce Clause had a far broader scope," claiming that "the Thomas/Epstein/Berger approach is historically unsound." They contend that "[ $t]$ he argument that the original meaning of 'to regulate commerce' was 'to govern all gainful activity' has never been refuted, and our independent research has corroborated it.".23

Now that in United States $v$ Morrison ${ }^{24}$ the Court has found another statute to be unconstitutional because it exceeded Congress's power under the Commerce Clause, ${ }^{25}$ it appears that the Court is seri-

14 Id at 13 n 50 ("Our historical analysis depends heavily upon two secondary sources.").

15 Walton H. Hamilton and Douglass Adair, The Power to Govern: The Constitution-Then and Now (W.W. Norton 1937).

16 William Winslow Crosskey, Politics and the Constitution in the History of the United States (Chicago 1953).

17 Nelson and Pushaw, 85 Iowa L Rev at 14 n 50 (cited in note 11).

18 See Albert S. Abel, The Commerce Clause in the Constitutional Convention and in Contemporary Comment, 25 Minn L Rev 432, 432 (1941) (evaluating materials from 1787 to 1788 to "discover what import was original to the clause").

19 Specifically, they criticize Richard A. Epstein, The Proper Scope of the Commerce Power, 73 Va L Rev 1387, 1388 (1987) (analyzing the structure of the federal government, the text of the Constitution, and other documentation to interpret the Commerce Clause, and coming to the conclusion that "the expansive construction of the clause by the New Deal Supreme Court is wrong").

20 See Raoul Berger, Judicial Manipulation of the Commerce Clause, 74 Tex L Rev 695, 703 (1996) (arguing that "commerce" as originally understood covered only "the interchange of goods by one state with another").

21 Nelson and Pushaw, 85 lowa $L$ Rev at 6 (cited in note 11). See also id at 101 ("Thomas, Berger, and Epstein do not even cite-much less refute - the massive evidence of this broader meaning.").

22 Id at 6.

23 Id at $14 \mathrm{n} 50$.

$24120 \mathrm{~S} \mathrm{Ct} 1740$ (2000).

25 Id at 1754 (holding that portions of the Violence Against Women Act unconstitutionally 
ous about finding some limit on the power to regulate commerce among the states. It is, therefore, well worth considering whether the narrow view of the Commerce Clause held by the Progressive Era Supreme Court, by Justice Thomas, as well as by Albert Abel, Richard Epstein, and Raoul Berger is as "historically unsound" as Nelson and Pushaw contend.

While I agree with much in Nelson and Pushaw's nuanced article $^{26}$ I will present evidence here that strongly indicates that they, Crosskey, and Hamilton and Adair are wrong with respect to the original meaning of the term "commerce" in the Commerce Clause. Indeed, when I first read Hamilton and Adair and Crosskey, alongside Nelson and Pushaw's endorsement of their work, I too was persuaded that "commerce" meant any "gainful activity" - until I had a chance to survey the records of the Constitutional Convention and the ratification debates for myself. When I did, I found to my surprise that the term "commerce" was consistently used in the narrow sense and that there is no surviving example of it being used in either source in any broader sense. The same holds true for the use of the word "commerce" in The Federalist Papers.

Upon discovering this, I returned to The Power to Govern and noticed for the first time that Hamilton and Adair omitted any reference to the use of the term "commerce" in the Philadelphia or ratification conventions, though they offered evidence from these sources for other claims. I was not surprised that Crosskey had omitted this evidence since he explicitly signaled his intention to ignore evidence from the drafting process. "The samples of word-usage and juristic and political discussion ... will ... all be drawn ... from sources not connected with the Constitution. ${ }^{28}$ Only after examining this evidence,

exceeded the powers of Congress under the Commerce Clause).

26 In particular, I agree with Nelson and Pushaw that even the broadest original meaning of the Commerce Clause that can be justified historically is still far narrower than the power the Supreme Court currently allows Congress to exercise. See Nelson and Pushaw, 85 Iowa L Rev at 119-72 (cited in note 11). I do not accept, however, all the doctrines they recommend for applying this broader, but still not limitless, conception of the Commerce Clause to actual cases and controversies-for example, their view that Congress may regulate any activity that "affects" commerce between more states than one, or the extreme deference they would give towards a congressional assessment of these effects. See id at 110-11.

27 For example, Hamilton and Adair use evidence from the ratification conventions to define the terms "traffic" and "trade." Hamilton and Adair, The Power to Govern at 54 \& n 37 (cited in note 15). The authors also use evidence from the ratifying conventions to argue that the states approved the use of the taxing power to regulate. Id at 121-27.

28 William Winslow Crosskey, 1 Politics and the Constitution in the History of the United States 5 (Chicago 1953). Crosskey defends this method as follows:

For, by using such materials, a dictionary can be made which will not, it is conceived, be open to the many natural suspicions that arise from the known or suspected political bias of speakers and writers on the Constitution. And in consequence of this, it should lead to con- 
however, did I discover just how convenient this deliberate omission was for Crosskey's thesis. Unfortunately, Nelson and Pushaw do not fill this gap.

After discussing the evidence concerning the meaning of "commerce," I will present evidence on the meaning of the terms "among the states" and "To regulate." Here I am in more agreement with Nelson and Pushaw, who seem to endorse a narrower interpretation of the original meaning of these terms, ${ }^{29}$ though I greatly disagree with their doctrinal implementation-or construction-of these aspects of the Commerce Clause.

Before attempting any of this, it is necessary to distinguish "original meaning" from "original intent" as methods of originalist interpretation. This distinction will assist in understanding why the evidence of meaning I present here is significant and why it is not undermined fatally by the contrary evidence relied upon by Nelson and Pushaw, Hamilton and Adair, and Crosskey. And it is also important to distinguish interpretation from construction so as to avoid asking too much of the former, or confusing the former with the latter.

\section{ORIGINAL MEANING AND INTERPRETATION}

\section{A. Original Meaning vs. Intent}

As I have explained elsewhere, "original meaning" refers to the meaning a reasonable speaker of English would have attached to the words, phrases, sentences, etc. at the time the particular provision was adopted. It is originalist because it disregards any change to that meaning that may have occurred in the intervening years. It is objective insofar as it looks to the public meaning conveyed by the words used in the Constitution, rather than to the subjective intentions of its framers or ratifiers. By contrast, "original intent" refers to the goals, objectives, or purposes of those who wrote or ratified the text. These intentions could have been publicly known - or hidden behind a veil of secrecy. They could and indeed were likely to be in conflict.

In sum, to use what Ronald Dworkin characterizes as a "crucial distinction," original meaning refers to "what some officials intended

stitutional conclusions having a very high and singular cogency.

Id at 5-6.

29 See, for example, Nelson and Pushaw, 85 Iowa L Rev at 42-49 (cited in note 11) ("Although Crosskey's interpretation is defensible, he did not marshall evidence strong enough to overcome the presumption that the regulation of commerce, like all federal power, does not extend to purely internal state affairs.").

30 The argument presented in this section is substantially elaborated and defended in Randy E. Barnett, An Originalism for Nonoriginalists, 45 Loyola L Rev 611 (1999).

31 Ronald Dworkin, Comment, in Antonin Scalia, A Matter of Interpretation: Federal Courts 
to say in enacting the language they used," whereas original intent refers to "what they intended-or expected or hoped-would be the consequences of their saying it." cepted, these original intentions could have shaped the original meaning of terms and, for this reason, they are not completely immaterial to an originalist analysis. But, at best, evidence of the framers' and ratifiers' intentions (as distinct from evidence of how they used the words they used) is circumstantial evidence of meaning while at worst it can distract from the words of the document that were actually employed.

The method to be preferred depends on one's normative rationale for originalism. Those who believe that we must pay attention to the framers or ratifiers because they were somehow authorized (by consent or something else) to issue binding commands to the rest of the population and to their posterity may want, for this reason, to determine the intentions or objectives that lie behind their words. In contrast, those who believe that the actions of the ratifiers established a rule of law that is binding if its content is "good enough" to be legitimate ${ }^{33}$ would want to use a writing to "lock-in" that meaning and, once locked in, adhere to it unless and until it is changed in writing. In short, a commitment to original intention originalism stems from the legitimacy of the founders as command givers. In contrast, a commitment to original meaning originalism need not be based on this rationale, but instead may stem from the legitimacy of the original commands themselves and the fact these commands were made in writing. ${ }^{3}$ A commitment to original meaning is, then, a crucial part of the commitment to a written constitution.

Original meaning originalism circumscribes the relevance of various types of historical evidence the way the objective theory of contract restricts the evidence relevant to determine the meaning of a written contract. With written constitutions, as with contracts, we want evidence of what the terms meant in the particular context of the written text at issue, whether a provision in the original Constitution or a later amendment. As Richard Posner has put the matter:

and the Law 115, 116 (Princeton 1997) (Amy Gutmann, ed).

32 Id.

33 By "legitimate" I mean a lawmaking process capable of producing laws that bind the citizenry in conscience. See Barnett, 45 Loyola $\mathrm{L} \mathrm{Rev}$ at $636-43$ (cited in note 30) (discussing original meaning and constitutional legitimacy); Randy E. Barnett, Getting Normative: The Role of Natural Rights in Constitutional Adjudication, 12 Const Commen 93, 98-99 (1995). I will greatly expand upon this analysis in a work-in-progress entitled The Presumption of Liberty: Natural Rights and the Constitution.

34 I defend the latter justification in Barnett, 45 Loyola L Rev at 636-48 (cited in note 30). 
Sophisticated originalists ... do not want to substitute amateurish inconclusive debates over history for professional but inconclusive debates over policy or values. They want, or at least ought to want, ... a narrowly focused inquiry into precise and answerable questions of historical meaning of specific words and sentences, coupled with a list of "canons of construction" that will enable those historical meanings to be brought to bear on contemporary issues.

This should lead us to prefer evidence of usage that is most closely associated with the measure's drafting and adoption. Where the chosen words had more than one established meaning, evidence of usage outside the context of drafting and ratification may mislead us as to what the particular words of a particular measure meant at the time of its enactment. Far from providing useful "context," such historical evidence may instead cloud what was otherwise a fairly clear meaning. The same is true of "contextual" evidence of the conflicting objectives or intentions of various actors. What is ultimately important is not what the framers or ratifiers intended to accomplish but what they succeeded in adopting and conveying to the public.

With original meaning, then, more "historical context" is not automatically preferred. To the contrary, originalism requires a limited focus on certain types of evidence of historical meaning: that evidence that most clearly indicates the public meaning of the text that is being interpreted at the time it was adopted. When it comes to determining original usage, dictionary definitions provide a useful start, but we must also immediately examine any clues to meaning provided in the document itself since any context it provides would directly influence the specific meaning perceived by the public when reading this text. After all, the document was far more accessible to the general public than any particular discussion of it. And it is the document that was adopted as law, not the statements of people about the document.

Where the document itself does not settle the matter, extrinsic evidence of how persons used words when discussing the particular text at issue will further narrow the scope of possible meanings. ${ }^{36}$ And

35 Posner, 67 U Chi L Rev at 595 (cited in note 10). Why Judge Posner does not think Justice Thomas's concurrence in Lopez fits this description of originalism is not clear to me and Posner does not attempt to explain his characterization. But if it truly is "law office history," though I disagree, then Justice Thomas happened to hit upon a conclusion that is well justified by the type of originalist inquiry that Posner seems to endorse.

36 We are confronted here with a "parol evidence rule"-type problem. How can we be sure what the meaning of a passage was unless we examine extrinsic evidence to determine the range of possible meanings it might have had? This is a good reason to consult evidence of usage found in dictionaries or in the drafting and ratification conventions. But once evidence of alternative possibilities is thereby revealed, we must then return to the text to see if the context $i$ provides 
the more closely in time these discussions are to the document's adoption, the less likely is the chance either that the meaning of words has changed, or the speaker is seeking to deviate from the original meaning of the text. Thus, evidence of usage in the Philadelphia and state ratification conventions illuminates the original meaning of the text, provided that this usage is not shown to be secret or unknown to the general public.

Of course, where evidence of meaning closely linked to drafting and ratification is missing or inadequate, we may need to cast a wider net. In addition, evidence removed from the immediate process of drafting and ratification can confirm our evaluation of more relevant evidence or provoke us to take a closer look at what we thought was clear evidence of original meaning. But it would be improper to let conflicting evidence either before or after drafting and ratification in any way trump evidence of a clear public meaning that existed during this process.

\section{B. Interpretation vs. Construction}

It is important to keep in mind that originalism is warranted as a theory of interpretation-that is, as a method of determining the meaning of the words written in the Constitution. For better or worse, knowing the meaning of these words only takes us so far in resolving current cases and controversies. Due either to ambiguity or vagueness, the original meaning of the text may not always determine a unique rule of law to be applied to a particular case or controversy. While not indeterminate, the original meaning can be "underdeterminate." Indeed, because the framers frequently used abstract language, this will often be the case. When this happens, interpretation must be supplemented by constitutional construction - within the bounds established by original meaning. In this manner, construction fills the unavoidable gaps in constitutional meaning when interpretation has reached its limits.

Keith Whittington distinguishes interpretation from construction in the following manner:

Constitutional interpretation is essentially legalistic, but constitutional construction is essentially political. Its precondition is that parts of the constitutional text have no discoverable meaning. Al-

excludes some of these possibilities or affirms others. If so, then the extrinsic evidence cannot be used to contradict the text. If not, extrinsic evidence may be used to clarify otherwise ambiguous passages, provided it is evidence of the contemporary meaning of the text being interpreted.

37 See Lawrence B. Solum, On the Indeterminacy Crisis: Critiquing Critical Dogma, $54 \mathrm{U}$ Chi L Rev 462, 473 (1987) (distinguishing between indeterminacy and underdeterminacy). 
though the clauses and structures that make up the text cannot be simply empty of meaning, for they are clearly recognizable as language, the meaning that they do convey may be so broad and underdetermined as to be incapable of faithful reduction to legal rules.... Regardless of the extent of judicial interpretation of certain aspects of the Constitution, there will remain an impenetrable sphere of meaning that cannot be simply discovered. The judiciary may be able to delimit textual meaning, hedging in the possibilities, but after all judgments have been rendered specifying discoverable meaning, major indeterminacies may remain. The specification of a single governing meaning from these possibilities requires an act of creativity beyond interpretation.... This additional step is the construction of meaning.

He then offers a very long list of constitutional constructions adopted either by courts in their opinions or by the other branches of government in legislation or executive orders that fill the gaps in the original meaning of the text and help "transform constitutional theory into constitutional practice., ${ }^{, 9}$

Though the process of constitutional construction fills the gaps within original meaning, I do not share Whittington's characterization of the process of construction as "political," insofar as this term implies that construction is necessarily and always political. Use of that phrase also connotes a completely open-ended choice unguided by constitutional principle. That is not, I think, even Whittington's conception of constitutional construction. Rather, there is often a gap between abstract or general principles of the kind found in the Constitution and the rules of law that are needed to put these principles into

38 Keith E. Whittington, Constitutional Interpretation: Textual Meaning, Original Intent, and Judicial Review 7 (Kansas 1999). See also Keith E. Whittington, Constitutional Construction: Divided Powers and Constitutional Meaning 1-19 (Harvard 1999) (discussing interpretation and construction, and arguing that construction is necessary because constitutional interpretation cannot answer every constitutional question).

39 Whittington, Constitutional Construction at 8,12 (cited in note 38). Whittington groups constructions into seven categories and I shall just give one example of each (without commenting on whether I think it is warranted): (1) organic structures--specification of the size of the Supreme Court; (2) delegation and distribution of political powers-judicial refusal to issue advisory opinions; (3) individual and collective rights - no right to secession; (4) structures of political participation/citizenship-specification of a single date for national elections; (5) jurisdiction-state annexation through treaty; (6) domestic government role-national bankruptcy law; and (7) international posture-entrance into NATO. Each of these actions by one or more branches of the government fleshes out how the government is "constituted" in ways that are not specified in the written Constitution. For the entire list of Whittington's examples, see id at 12. Note that in several instances he lists constructions that oppose each other, for example, "federal incorporation of banks" and "no federal incorporation of banks." Id. 
action. ${ }^{40}$ This does not mean, however, that the choice of rules is unguided by the abstract or general principles that can be ascertained by interpretation.

Many parts of the Constitution are rule-like and can often be applied directly to cases without need of intermediate doctrine. ${ }^{41}$ Other provisions are abstract and general and require some choice among possible ways of putting them into effect. ${ }^{42}$ Still other provisions explicitly refer to standards or principles that lie outside the text and therefore authorize supplementation of the text by other materials." When, for these reasons, the terms of the Constitution cannot directly be applied to resolve a particular dispute, some construction, as opposed to interpretation, of constitutional meaning is required. As Whittington observes, constructions operate "where the text is so broad or so underdetermined as to be incapable of faithful but exhaustive reduction to legal rules." ${ }^{44}$

Constitutional constructions, then, are not wholly "political." The choices among possible constructions, while not dictated by original meaning interpretation, can be and often are limited by that meaning. In this way, constitutional constructions, though not identical with the text nor deduced immediately from it, are not unconnected or unconstrained by the text. The text provides what Frederick Schauer has called a "frame" that excludes many constructions without determining one unique construction that would put into action the general principles it enunciates. "The language of a [constitutional] clause, whether seemingly general or seemingly specific, establishes a boundary, or a frame, albeit a frame with fuzzy edges. Even though the language itself does not tell us what goes on within the frame, it does tell us when we have gone outside it." constructions are not in the Constitution, they can be of the Constitution.

Apart from revealing the limits of interpretation, the distinction between interpretation and construction also helps us to understand the differing appeals of original meaning and original intent originalism. The former looks to original usage to determine the meaning of

40 See Randy E. Barnett, The Structure of Liberty: Justice and the Rule of Law 108-31 (Oxford 1998) (explaining why conventional rules of law are needed to put abstract and underdeterminate principles of justice into effect). $\S 1, \mathrm{cl} 5$

41 The oft-cited example is the Presidential age limit of thirty-five years in US Const Art II,

42 See, for example, the phrase "cruel and unusual" in US Const Amend VIII.

43 Consider the Ninth Amendment's reference to unspecified "other[ ]" rights "retained by the people." US Const Amend IX.

44 Whittington, Constitutional Construction at 5 (cited in note 38).

45 Frederick Schauer, Easy Cases, 58 S Cal L Rev 399, 430 (1985) (footnotes omitted). 
the text, though this meaning may require construction due to ambiguity and vagueness. So long as we stay within the frame provided by the original meaning of the text, our choice of specific rules to decide cases may be influenced by other considerations, such as justice or precedent, depending on what it is we think makes a constitution binding.

Some originalists, however, seek to go beyond the original meaning of the text to identify the specific constructions that would have been preferred or intended by the framers or ratifiers. Often this is done by "channeling the framers," that is, by hypothesizing what the framers would have intended had they been presented with the case at hand. I do not think that the normative case for original meaning originalism entails a commitment to construction according to the original intentions of the framers or ratifiers. ${ }^{46}$ This is not to deny that some of the founders might usefully be consulted to determine a construction that best fits the underlying principles of the constitution they wrote and approved. In this manner, the framers as the designers of the Constitution become our teachers rather than our wardens.

There is then an important distinction between determining the original meaning of text and construing that meaning, where it is vague or ambiguous, according to the original intentions of its drafters or ratifiers. In what follows, I present what I think is the best evidence of the original meaning of the Commerce Clause. How that meaning, once established, is to be construed is a different matter that I may touch upon in passing, but is not the primary focus of this Article.

\section{THE ORIGINAL MEANING OF "COMMERCE"}

The Commerce Clause raises three questions that must be answered by interpretation, construction, or both: What is the meaning of "Commerce"? What is the meaning of "among the several States"? And what is the meaning of "To regulate"? The source of the scholarly debate lies in the fact that, unlike some other provisions of the Constitution, the evidence of "original intent, meaning, and understanding" is in conflict. This is because there was a clash of objectives among different supporters of the Constitution, not to mention a clash between supporters and opponents. And unlike other passages of the Constitution, each of the terms of the Commerce Power is said to have had, at

46 See Barnett, 45 Loyola L Rev at 611-14 (cited in note 30) (discussing the significant problems with "original intent" originalism while suggesting that the new originalism has "virtually triumphed over other interpretive techniques").

47 See Randy E. Barnett, The Relevance of the Framers' Intent, 19 Harv J L \& Pub Pol 403, 403 (1996) (distinguishing between the "framers as wardens" and the "framers as designers").

48 Nelson and Pushaw, 85 Iowa L Rev at 13 (cited in note 11). 
the time of the founding, both an expansive and more limited meaning in common discourse (though not, as we shall see, in the context of the drafting and ratifying of the Constitution).

"Commerce" might be limited to trade or exchange of goods, which would exclude, for example, agriculture, manufacturing, and other methods of production, or it might expansively be interpreted to refer to any gainful activity. "To regulate" might be limited to "make regular," which would subject a particular type of commerce to a rule and would exclude, for example, any prohibition on trade as an end in itself, or it might expansively be interpreted to mean "to govern," which would include prohibitions as well as pure regulations. "[A]mong the several States" might be limited to commerce that takes place between the states (or between people of different states), as opposed to commerce that occurs between persons of the same state. Or "among the states" might expansively be interpreted to refer to commerce "among the people of the States," whether such commerce occurs between people in the same state or in different states.

Though it is often difficult to be sure of the meaning intended by a speaker from the context of a particular statement, there are good textual and contextual reasons to accept the narrower definition of each of these terms as their original meaning at the time of the founding. Because the meaning of the term "commerce" has been the most contentious, I will spend more time evaluating the evidence of its original meaning than that of the others.

I was surprised to find, given the degree of scholarly criticism of the narrow meaning, that the use of the term "commerce" in the drafting and ratification process was remarkably uniform. Indeed, I have found not a single example from the reports of these proceedings that unambiguously used the broad meaning of "commerce" and many instances where the context makes clear that the speaker intended a narrow meaning.

\section{A. Originalist Sources}

1. The text.

The first place to look for the original meaning of the text is the text itself, both the immediate text at issue and any other text in the Constitution that may shed light on the meaning of the relevant portion. In sum, does the Constitution serve as its own dictionary on the meaning of a particular word? When considering the meaning of the term "commerce," it is tempting to argue that "commerce" must mean trade, and not manufacturing or agriculture, because it would make no sense to refer to a congressional power "to regulate manufacturing with foreign nations" or "to regulate agriculture with Indian tribes." 
This temptation should be resisted, however. For, if we plug the broadest meaning of "commerce"-that is, "gainful activity"-into the sentence so it reads Congress shall have power "to regulate gainful activity with foreign nations," the sentence makes perfect sense. While it is true that the clause would be referring only to that subset of gainful activity that can be conducted "with foreign nations" and "with the Indian tribes" and that this would exclude manufacturing and agriculture, this would not be due to any narrow meaning of "commerce," but because of the narrowing meaning of "with foreign nations" and "with Indian tribes." In other words, the word "commerce" could still be used in its broadest sense in a manner that does justice to the sentence as a whole. Therefore, while this sort of textual analysis may well reveal what the term "among the several States" means, ${ }^{49}$ it does not tell us in which sense, narrow or broad, the word "commerce" is being used in the Commerce Clause, and we must look elsewhere for guidance.

A bit more assistance is provided from the way "commerce" is used in Article I, Section 9, which reads: "No Preference shall be given by any Regulation of Commerce or Revenue to the Ports of one State over those of another. ..."., Here, as Richard Epstein has written, " $[\mathrm{t}] \mathrm{he}$ term 'commerce' is used in opposition to the term 'revenue,' and seems clearly to refer to shipping and its incidental activities; this much seems evident from the use of the term 'port.", Moreover, unlike the Commerce Clause, we cannot here comfortably substitute "gainful activity" for the term "commerce." "No Preference shall be given by any Regulation of gainful activity to the Ports of one State over those of another" is too awkward to be an accurate translation. But though in Article I, Section 9, the term "commerce" is, all by itself, ${ }^{52}$ pretty clearly being used in a much narrower sense than "any gainful activity," we cannot be sure from this usage exactly what this sense is. For that we need to appeal to extrinsic evidence of original meaning that lies outside the four corners of the Constitution.

\section{Contemporary dictionaries.}

Commerce is defined in the 1785 edition of Samuel Johnson's Dictionary of the English Language as "1. Intercourse; exchange of one thing for another; interchange of any thing; trade; traffick." ${ }^{53}$ In

\footnotetext{
See Part III.A.

US Const Art I, $\$ 9, \mathrm{cl} 6$.

Epstein, 73 Va L Rev at 1395 (cited in note 19).

52 By this I mean the narrowing sense is not provided by some other phrase such as "with

53 Samuel Johnson, 1 A Dictionary of the English Language (J.F. Rivington, et al 6th ed
} foreign Nations." 
contrast, "manufacture" is defined as " 1 . The practice of making any piece of workmanship. 2. Any thing made by art." "Agriculture" is defined as "[ $\mathrm{t}]$ he art of cultivating the ground; tillage; husbandry, as distinct from pasturage.". If Johnson is accurate, commerce referred predominantly to exchange or trade as distinct from the agricultural or manufacturing production of those things that are subsequently traded. As Justice Thomas noted in his concurrence, Johnson's definition of "commerce" is borne out by other dictionaries of the time. It is also the usage most closely associated with the drafting and adoption of the Constitution.

Nelson and Pushaw acknowledge that "trade and exchange" is the core meaning of "commerce." The question is whether they are right to claim that "[a]bundant evidence demonstrates, however, that 'commerce' had other broader meanings, which a significant number of the Constitution's Framers and Ratifiers intended to incorporate." ", While their evidence showed that a number of framers and ratifiers may have desired a government powerful enough to control all aspects of the national economy, the issue is whether the term "commerce" that was chosen to describe the powers of Congress conveyed that expansive meaning to those to whom it was addressed and whether the public statements of those who supported the Constitution and favored broad national powers reflected such a meaning. If "commerce" had been used in its broad sense, we would expect this usage to appear somewhere in the records of the Constitution's drafting and ratification. But no such example exists.

\section{Constitutional Convention.}

In Madison's notes for the Constitutional Convention, the term "commerce" appears thirty-four times in the speeches of the delegates. ${ }^{59}$ Eight of these are unambiguous references to commerce with foreign nations which can only consist of trade. In every other instance, the terms "trade" or "exchange" could be substituted for the term "commerce" with the apparent meaning of the statement pre-

1785). $1785)$

Samuel Johnson, 2 A Dictionary of the English Language (J.F. Rivington, et al 6th ed

Johnson, 1 A Dictionary of the English Language (cited in note 53).

See note 3.

57 See Nelson and Pushaw, 85 Iowa L Rev at 101 n 478 (cited in note 11) ("We readily concede that in the eighteenth century (1) the primary definition of 'commerce' was the one proffered by Thomas, Berger, and Epstein, and (2) some may have thought that this was the meaning conveyed in the Commerce Clause.").

58 Id.

59 This is apart from the sixteen times in which it appears in quotes from various proposals. 
served. In no instance is the term "commerce" clearly used to refer to "any gainful activity" or anything broader than trade. One congressional power proposed by Madison, but not ultimately adopted, suggests that the delegates shared the limited meaning of "commerce" described in Johnson's dictionary. Madison proposed to grant Congress the power " $\mathrm{t}] \mathrm{o}$ establish public institutions, rewards, and immunities for the promotion of agriculture, commerce, trades and manufactures, ${ }^{, 60}$ strongly suggesting that the members understood the term "commerce" to mean trade or exchange, distinct from the productive processes that made the things to be traded.

\section{The Federalist Papers.}

Nor was this a secret usage confined to the Convention. In several of his contributions to The Federalist Papers, ardent nationalist Alexander Hamilton repeatedly made clear the commonplace distinction between commerce or trade and production. In Federalist 11, he also explained the purpose of the Commerce Clause, a purpose entirely consistent with the prevailing "core" meaning of the term "commerce":

An unrestrained intercourse between the States themselves will advance the trade of each by an interchange of their respective productions, not only for the supply of reciprocal wants at home, but for exportation to foreign markets. The veins of commerce in every part will be replenished and will acquire additional motion and vigor from a free circulation of the commodities of every part. Commercial enterprise will have much greater scope from the diversity in the productions of different States."

In Federalist 12, he referred to the "rivalship," now silenced, "between agriculture and commerce," guished between the power to regulate such national matters as commerce and "the supervision of agriculture and of other concerns of a similar nature, all those things, in short, which are proper to be provided for by local legislation." ${ }^{63}$ In Federalist 21, Hamilton maintained that causes of the wealth of nations were of "an infinite variety," including "[s]ituation, soil, climate, the nature of the productions, the na-

60 James Madison, Notes of Debates in the Federal Convention of 1787478 (W.W. Norton 1987) (emphasis added). The term "trades" connotes crafts and other types of trades, not trade or exchange.

61 Federalist 11 (Hamilton), in Clinton Rossiter, ed, The Federalist Papers 89 (Penguin 1961).

62 Federalist 12 (Hamilton), in Rossiter, ed, The Federalist Papers at 91 (cited in note 61).

63 Federalist 17 (Hamilton), in Rossiter, ed, The Federalist Papers at 118 (cited in note 61). 
ture of the government, the genius of the citizens, the degree of information they possess, the state of commerce, of arts, of industry.," In Federalist 35, he asked, "Will not the merchant understand and be disposed to cultivate, as far as may be proper, the interests of the mechanic and manufacturing arts to which his commerce is so nearly allied?",5

In none of the sixty-three appearances of the term "commerce" in The Federalist Papers is it ever used to unambiguously refer to any activity beyond trade or exchange. At the time of the framing, then, for Hamilton, a proponent of broad national powers, the term "commerce" in the Constitution referred to trade or exchange, not to the production of items to be traded, and certainly not to all gainful activity. Even later, with the contentiousness of the Constitution's adoption behind him, Hamilton's usage did not change. As Secretary of the Treasury, Hamilton's official opinion to President Washington advocating a broad congressional power to incorporate a national bank repeatedly referred to Congress's power under the Commerce Clause as the power to regulate the "trade between the States."

\section{Ratification conventions.}

Having examined every use of the term "commerce" that appears in the reports of the state ratification conventions, I found that the term was uniformly used to refer to trade or exchange, rather than all gainful activity. Because people used this word to convey its accustomed meaning, they did not often define it or give contextual clues as to what they believed the term meant. Yet some of these public speeches make clear that "commerce" was used as a synonym for trade or exchange - and did not include agriculture, manufacturing, or other business-and every speech is consistent with such a meaning (though I will discuss two statements that can be misinterpreted as connoting a broader meaning of "commerce"). I shall present this evidence state by state.

In the records of the Massachusetts convention, the word "commerce". is used nineteen times-every use consistent with it meaning trade, mostly foreign trade; and no use clearly indicating a broader meaning. The most explicit distinction was made by Thomas Dawes, a prominent revolutionary and legislator, who began his discussion on

64 Federalist 21 (Hamilton), in Rossiter, ed, The Federalist Papers at 141 (cited in note 61).

65 Federalist 35 (Hamilton), in Rossiter, ed, The Federalist Papers at 216 (cited in note 61).

66 Alexander Hamilton, Final Version of an Opinion on the Constitutionality of an Act to Establish a Bank (Feb 23, 1791), in Harold C. Syrett, et al, eds, 8 The Papers of Alexander Hamilton 97,100 (Columbia 1965). See also id at 118 (referring to "the regulation of trade between the states"). 
the importance of the national taxation powers. "We have suffered," said he, "for want of such authority in the federal head. This will be evident if we take a short view of our agriculture, commerce, and manufactures." ${ }^{167} \mathrm{He}$ then expounded at some length, giving separate attention to each of these activities and the beneficial effect the Constitution would have on them. ${ }^{68}$ Under the heading of "commerce," he referred to "our own domestic traffic that passes from state to state.",

Only two other speakers in the Massachusetts convention implicitly distinguished between "commerce" and other economic activities. Charles Turner referred to "the deplorable state of our navigation and commerce, and various branches of business thereon dependent." And making much the same point, James Bowdoin of Boston argued that the existing confederation lacked the power to retaliate against foreign nations who placed restrictions on American exports:

Hence a decrease of our commerce and navigation, and the duties and revenue arising from them. Hence an insufficient demand for the produce of our lands, and the consequent discouragement of agriculture. Hence the inability to pay debts, and particularly taxes, which by that decrease are enhanced. And hence, as the necessary result of all these, the emigration of our inhabitants.

While each of these further consequences flowed from a decrease of "our commerce and navigation," they were not the same thing as commerce.

In the few fragments that survive of the Maryland, Connecticut, and New Hampshire ratification debates, the term "commerce" is mentioned only once. In the opening address to the Connecticut convention, Oliver Elsworth referred to the Swiss who "[t]ill lately," he said, "had neither commerce nor manufactures. They were merely a set of herdsmen." New York convention, the term appears thirty times. Governor Clinton referred to "[t]he situation of [each state's] commerce, its agriculture, and the system of its resources." ${ }^{, 73}$ Another delegate questioned the need for the new central government by noting the rapid eco-

67 Jonathan Elliot, ed, 2 The Debates in the Several State Conventions on the Adoption of the Federal Constitution 57 (Taylor \& Maury 2d ed 1863).

68 Id at 57-59.

69 Id at 58 .

70 Id at 170 .

71 Id at 83 .

72 Id at 188 .

73 Id at 261. 
nomic progress: "How [the country's] agriculture, commerce, and manufactures have been extended and improved!"

The New York delegate who repeatedly made the clearest distinction between commerce and other economic activity was Alexander Hamilton. As part of a lengthy speech, he observed: "The Southern States possess certain staples, - tobacco, rice, indigo, \&c., - which must be capital objects in treaties of commerce with foreign nations." ${ }^{75}$ The same distinction is implicit in his denial that the regulation of commerce was outside the competency of a central government: "What are the objects of the government? Commerce, taxation, \&c. In order to comprehend the interests of commerce, is it necessary to know how wheat is raised, and in what proportion it is produced in one district and in another? By no means." ${ }^{, 6}$ Later, in defending the power of direct taxation, Hamilton predicted that in its absence, the "general government ... will push imposts [on our commerce] to an extreme." As a result, "[o]ur neighbors, not possessed of our advantages for commerce and agriculture, will become manufacturers: their property will, in a great measure, be vested in the commodities of their own productions; but a small proportion will be in trade or in lands. Thus, on the gentleman's scheme, they will be almost free from burdens, while we shall be loaded with them."

Although there is no example in New York of a clear use of "commerce" in any sense broader than trade or exchange, two statements might mistakenly be so interpreted. In one, Hamilton argued that "one man can be as fully acquainted with the general state of the commerce, manufactures, population, production, and common resources of a state, which are the proper objects of federal legislation." Although here, as elsewhere, he uses the term "commerce" narrowly, this passage might be read to indicate that the entire list of activities fell within the power of Congress to regulate commerce among the states. Taken in context, this would be a misreading. Rather, Hamilton is contending here, as he did throughout his career and as did many others, that the advancement of all these economic activities was the proper goal of national legislation. He is not speaking of the specific means or powers granted to Congress by the Constitution to pursue 
these ends, such as the power of taxation and the power to regulate commerce with foreign nations or among the states.

Referring to the same problem of knowledge, antifederalist Melancton Smith asserted:

To understand the true commercial interests of a country, not only requires just ideas of the general commerce of the world, but also, and principally, a knowledge of the productions of your own country, and their value, what your soil is capable of producing, the nature of your manufactures, and the capacity of the country to increase both.

Although this statement employs the term "commercial interests" broadly, it still uses the narrow conception of "commerce" as distinct from "productions" and "manufactures" as included among these "commercial" interests.

Smith's statement is extremely useful because many of the quotes employed by Crosskey and others as evidence of a broader meaning actually use the term "commercial," not "commerce." Nelson and Pushaw repeatedly use the term "commercial" throughout their article as though it were synonymous with "commerce," and a great many of the sources on which they rely to establish the broader meaning of "commerce" actually use the term "commercial" instead. ${ }^{82}$ While it seems reasonable at first blush to think that both terms have the same meaning, the statement by Smith undercuts this assumption by explicitly using "commercial interests" to convey a broader meaning than the term "commerce." In sum, the original meaning of the regulatory

80 The same is true of Chancellor Livingston's argument that:

Some gentlemen suppose that, to understand and provide for the general interests of commerce and manufactures, our legislators ought to know how all commodities are produced, from the first principle of vegetation to the last polish of mechanical labor; that they ought to be minutely acquainted with all the process of all the arts. If this were true, it would be necessary that a great part of the British House of Commons should be woollen-drapers; yet we seldom find such characters in that celebrated assembly.

Id at 275.

81 Id at 245 (emphasis added).

82 See, for example, Nelson and Pushaw, 85 Iowa L Rev at $40 \mathrm{n} 163$ (cited in note 11) (citing Charles Pinckney's reference at the Constitutional Convention to the five "commercial interests" of the American states as including staple crops such as "wheat," "tobacco," and "Rice \& Indigo," as well as "fisheries" and "trade" as evidence that he held a broad view of "commerce"). Pinckney's statement can be read as enumerating the different sources throughout the states of various articles of commerce. In no way does his list comprehend all gainful activities. In addition, I shall offer examples below showing that, to the contrary, Pinckney publicly used the term "commerce" in the narrow sense. See text accompanying notes 93-97.

83 Johnson's definition of "commercial" is: "Commercial: adj [from commerce]. Relating to commerce or traffick." Johnson, 1 A Dictionary of the English Language (cited in note 53). The pairing of "commerce" with "traffick" suggests that both "commerce" and "commercial" are be- 
powers granted to Congress might have been broader had Article I, Section 8 granted it the power "to regulate the commercial interests of the States" rather than the power to regulate only "commerce.",

The term "commerce" appears only eight times in the report of the Pennsylvanid ratification convention. All uses are consistent with the narrow meaning of "commerce"; none clearly uses a broader meaning. Only three uses add any context to the term, and all are by James Wilson, a member of the Constitutional Convention and a person who Nelson and Pushaw claim understood the term "commerce' as encompassing not merely the buying and selling of goods, but also antecedent production, labor-and-wage transactions, and related business services like insurance.", Wilson, they say, "used 'commerce' to describe all gainful activity." In the Philadelphia convention, however, Wilson referred to "the objects of commerce," being traded. Later he asked, "Is it not an important object to extend our manufactures and our commerce? This cannot be done, unless a proper security is provided for the regular discharge of contracts. This security cannot be obtained, unless we give the power of deciding upon those contracts to the general government." "His most revealing comment suggesting a strong distinction between "commerce" and other economic activities was this:

Suppose we reject this system of government; what will be the consequence? Let the farmer say, he whose produce remains unasked for; nor can he find a single market for its consumption,

ing used in the narrow sense.

84 Though the original meaning of "between the States" might still have greatly limited the scope of this power. See Part III.A.2.

85 Nelson and Pushaw, 85 Iowa L Rev at 19 (cited in note 11).

86 Id at $19 \mathrm{n} 74$ (citing statements made by Wilson during the 1790s in his lectures on law delivered at the College of Philadelphia). Unfortunately, their characterizations of these later quotes are misleading. In two, the intended meaning is not made plain by Wilson, and he may well have been referring only to trade. In a third, the only one in which Wilson's meaning is clear, their parenthetical characterizes Wilson as: "remarking that the United States had "extensive prospects of commerce' because of its favorable conditions for agriculture and production." Id at 19-20 $\mathrm{n} 74$. Not only does this parenthetical fail to support their claim that Wilson used the term "commerce" in the broadest sense, in the passage being cited, Wilson is quite clearly using "commerce" in its narrow sense to mean "trade or exchange":

The United States have the most extensive prospects of commerce before them... [T]he number and value of their productions furnish them with abundant materials to exchange for the manufactures and refined commodities of Europe and of Asia. The genius of their governments is favorable to trade, because it is favourable to equality and industry, the only pillars, on which trade can be supported.

Robert Green McCloskey, ed, The Works of James Wilson 491 (Belknap 1967) (emphases added).

87 Elliot, ed, 2 Debates in the Several State Conventions at 467 (cited in note 67).

88

Id at 492 . 
though his fields are blessed with luxuriant abundance. Let the manufacturer, and let the mechanic, say; they can feel, and tell their feelings. Go along the wharves of Philadelphia, and observe the melancholy silence that reigns. ... Let the merchants tell you what is our commerce.

In the North Carolina debates, "commerce" is mentioned eighteen times (including two times in proposed amendments). Like elsewhere, there is no clear use of it in any sense broader than "trade" or "exchange," and there are a few clear examples of its use in the narrow sense in speeches by William Davie. Davie defined the "general objects of the union" to be " 1 st, to protect us against foreign invasion; $2 \mathrm{~d}$, to defend us against internal commotions and insurrections; $3 \mathrm{~d}$, to promote the commerce, agriculture, and manufactures, of America." Later, he explained why the regulation of commerce, though distinct from agriculture and manufacturing, promoted them: "Commerce, sir, is the nurse of both. The merchant furnishes the planter with such articles as he cannot manufacture himself, and finds him a market for his produce. Agriculture cannot flourish if commerce languishes; they are mutually dependent on each other." And, Davie also distinguished between the interests "of agriculture and commerce" and how the Constitution would protect just claims of "the merchant or farmer." Merchants were those who bought and sold goods; it was they, not farmers or artisans, who engaged in commerce.

In the reports of the South Carolina convention, the word "commerce" is used twenty-six times. Charles Pinckney, who had been a delegate to the Constitutional Convention and whose use of the term "commercial interests" Nelson and Pushaw cite as evidence of a broad meaning of the term "commerce," equated "the regulation of commerce" and mere "privileges with regard to shipping," when he asked, "[i]f our government is to be founded on equal compact, what inducement can [the Eastern states] possibly have to be united with us, if we do not grant them some privileges with regard to their shipping?" Later, he distinguished between those "people [who] are employed in cultivating their own lands" and "the rest [who are] in handicraft and commerce." And he immediately expanded upon this

89 Id at 524.

90 Jonathan Elliot, ed, 4 The Debates in the Several State Conventions on the Adoption of the Federal Constitution 17 (Taylor \& Maury 2d ed 1863).

91 Id at 20.

92 Id at 159.

93 See text accompanying note 82 .

94 Elliot, ed, 4 Debates in the Several State Conventions at 284 (cited in note 90).

95 Id at 321. 
by discussing the different "classes" of society comprised of the "commercial men," the "professional men," those engaged in "the mechanical," and the "landed interest - the owners and cultivators of the soil." "And although he contended that all the other classes should be subservient to the promotion of the last, he defended commerce from the criticism that it was "generally cheating." No other use of the term connoted a broader meaning of "commerce"; all uses were entirely compatible with the terms "trade" or "exchange."

Virginia wins the prize for the most mentions of the word: seventy-four. Here, as elsewhere, there is not a single instance of "commerce" being used unambiguously in the broader sense. To the contrary, the most striking evidence is the dominance of a conception of commerce that is even narrower than "trade" or "exchange"-also manifested by Pinckney's reference in the South Carolina debates to "privileges with regard to shipping." "98 In Virginia, I count at least seventeen references that link "commerce" in some way to ports, shipping, navigation, or the "carrying trades." In other words, on these occasions, the term "commerce" is limited to conveying or transporting the articles of trade, rather than to the entire act of trading."

For example, Richard Henry Lee asked those who doubted the need for the Constitution to "go to our seaports; let him see our commerce languishing - not an American bottom to be seen." Edmund Randolph urged members to "[c]ast your eyes to your seaports: see how commerce languishes." $\mathrm{He}$ observed that "Virginia is in a very unhappy position with respect to the access of foes by sea, though happily situated for commerce," mercial nations to engross as much as possible the carrying trade, this makes it necessary to defend our commerce." Randolph, Francis Corbin also referred to those ports

96 Id at 321-22. This usage also suggests that "commercial" could be used in a narrow as well as a broad sense.

97 Id at 322 (stating that "there are some kinds of commerce not only fair and valuable, but such as ought to be encouraged by government").

98 See text accompanying note 94 .

99 On the other hand, these usages could be construed as somewhat expanding the scope of "commerce" to include trade and exchange "as well as," in the words of Justice Thomas, "transporting for these purposes." Lopez, 514 US at 585. Even so expanded, however, the original meaning of "commerce" would not embrace agriculture, manufacturing, or other productive activity. I will discuss this at greater length below in the context of Gibbons $v$ Ogden. See text accompanying notes $117-37$.

100 Jonathan Elliot, ed, 3 The Debates in the Several State Conventions on the Adoption of the Federal Constitution 43 (Taylor \& Maury 2d ed 1863).

101 Id at 66.

102 Id at 72 .

103 Id at 78 . 
where we had every reason to see the fleets of all nations, he will behold but a few trifling little boats; he will every where see commerce languish; the disconsolate merchant, with his arms folded, ruminating, in despair, on the wretched ruins of his fortune, and deploring the impossibility of retrieving it."

Future Chief Justice John Marshall asked whether "the Algerines ... and every other predatory or maritime nation, [cannot] pillage our ships and destroy our commerce, without subjecting themselves to any inconvenience?" can do it with advantage, may carry on the commerce of the contending nations." ${ }^{106}$ William Grayson stated that the riches of all those "maritime powers of Europe ... come by sea. Commerce and navigation are the principal sources of their wealth." shall, James Innes asked, "Is it not in the power of any maritime power to seize our vessels, and destroy our commerce, with impunity?"

I present all these quotes not to show that the original meaning of the term "commerce" was limited to shipping. Surely shipping was so closely identified with commerce because it was at that time the indispensable means for the movement of goods. One could easily extend this preoccupation with what is now called the "channels and instrumentalities" of commerce to railroads, canals, and air transport. But this close connection reinforces the narrow meaning of commerce and the purpose for granting Congress the power to regulate it. It also explains why the earliest cases involving the commerce power had to do with boats.

Moreover, these were not the only references to "commerce" in Virginia. Others of the sort I have canvassed from elsewhere appear here as well. Edmund Pendleton, for instance, viewed "commerce" as the means by which "the people may have an opportunity of disposing of their crops at market, and of procuring such supplies as they may be in want of." So synonymous was "commerce" with "trade" that William Grayson worried that "the whole commerce of the United States may be exclusively carried on by merchants residing within the

104 Id at 105.

105 Id at 235.

106 Id at 249.

107 Id at 428.

108 Id at 635 .

109 See, for example, Gibbons v Ogden, 22 US (9 Wheat) 1 (1824) (invalidating an exclusive navigation license granted by the New York state legislature).

110 Elliot, ed, 3 Debates in the Several State Conventions at 295 (cited in note 100). 
seat of government." ${ }^{\text {,11 }}$ He surely could not have been including agriculture or manufacturing in his definition of commerce.

Despite the strength and consistency of all this evidence, it is also true that persons participating in the process of drafting and ratifying the Constitution frequently used the phrase "trade and commerce."112 This, in the absence of the evidence already presented, might suggest that these terms were not identical. ${ }^{113}$ On the other hand, if "commerce" is given its broadest connotation as "gainful activity," it would include "trade" within its meaning, and this phrase would still make little sense. Instead, it appears that the phrase "trade and commerce" was something of a couplet like "cease and desist" or, as they say in Disney World, a "full and complete" stop. The couplet "trade and commerce" refers to a single activity that could be, and usually was, called either trade or commerce. Indeed, on two occasions, state convention delegates referred to the power to "regulate trade" rather than to the power to regulate "commerce.",

Should there be any doubt about my interpretation of these statements, go back to the quotes in which there is a context provided and replace the term "commerce" with the term "gainful activity." All of these sentences would be rendered incoherent. Nor are these statements to be dismissed, as Crosskey would have us do, ${ }^{115}$ because they occur in partisan debate. Remember, we are not asking what purposes or intentions are being expressed by these delegates. We are just asking how they used the term "commerce." So far as these records permit us to judge, there is no conflict over the meaning of this term among the otherwise divided participants in these conventions.

From these findings, we can conclude that if anyone in the Constitutional Convention or the state ratification conventions used the term "commerce" to refer to something more comprehensive than "trade" or "exchange," they either failed to make explicit that meaning or their comments were not recorded for posterity. The evidence

111 Id at 291.

112 Max Farrand, ed, 1 The Records of the Federal Convention of 1787 243, 263 (Yale 1966).

113 See, for example, Nelson and Pushaw, 85 Iowa L Rev at $36 \mathrm{n} 143$ (cited in note 11) ("For example, a broad definition of commerce may be inferred from the Framers' frequent use of the phrase 'trade and commerce.' . . 'Trade' generally connotes buying and selling goods. . . Thus, 'commerce' must have meant something more, or else the couplet 'trade and commerce' would have been redundant.").

114 See Elliot, ed, 2 Debates in the Several State Conventions at 80 (cited in note 67) ("Why not give Congress power only to regulate trade?"); Elliot, ed, 4 Debates in the Several State Conventions at 70 (cited in note 90) ("[I]t was well known he was for giving power to Congress to regulate the trade of the United States."). It is possible, though I think implausible given the context, to infer that these two speakers were advocating a power narrower than the power to regulate "commerce."

115 See note 28. 
that survives is entirely consistent on this point and confirms the observation made by Madison late in his life that "[i]f, in citing the Constitution, the word trade was put in the place of commerce, the word foreign made it synonymous with commerce. Trade and commerce are, in fact, used indiscriminately, both in books and in conversation."

\section{B. Judicial Interpretations of Commerce, 1824-1935}

Thirty-five years after ratification, in the 1824 case of Gibbons $v$ Ogden, ${ }^{17}$ John Marshall was called upon to decide whether navigation was included in the power of Congress to regulate commerce among the states. ${ }^{118}$ He held that it was. From the perspective of original intent, this holding is unremarkable. The above sources, and others unmentioned, ${ }^{119}$ make clear the intention to subject shipping and navigation to the regulation of Congress. The interpretive challenge is in determining exactly how, if at all, navigation is included in the original meaning of the text. Was it a part of the term "commerce" itself? Or was the regulation of navigation incidental to the regulation of commerce and therefore authorized by the Necessary and Proper Clause? Then there is always the possibility that the framers used words the original meaning of which did not accurately express their intentions, and so they failed to include a power over "navigation" though they believed they had.

While the sources I have examined do not provide indisputable answers to these questions, on balance, I think navigation appears to be included within the meaning of the term "commerce" because of its intimate connection to the activity of trading. Indeed, as was noted earlier, the etymology of the term "commerce" is "with" (com) "merchandise" (merci), a phrase that could accurately be applied to the "carrying trade," which is how the object of navigation laws was frequently described. ${ }^{121}$ Perhaps the strongest evidence that "commerce"

116 James Madison, Letter to Professor Davis-not sent (1832), in Galliard Hunt, ed, 4 Letters and Other Writings of James Madison 232, 233 (J.B. Lippincott 1865).

11722 US (9 Wheat) 1 (1824).

118 Id at 193.

119 Several proposals in the Constitutional Convention to require a supermajority for the passage of navigation acts make it clear that such acts were thought to be within the powers of Congress even after the Convention moved to an enumeration of powers. See, for example, Max Farrand, ed, 2 The Records of the Federal Convention of 1787143 (Yale 1966) (proposal in Edmund Randolph's handwriting to the Committee of Detail); id at 169 (proposal in James Wilson's handwriting to Committee of Detail); id at 183 (proposal of Committee of Detail). The Committee eventually struck the proposal. See id at 400 .

120 See 3 Oxford English Dictionary at 552 (cited in note 4) (com-"with"; merci"merchandise").

121 See, for example, statement of Edmund Randolph quoted above in text accompanying note 101 . 
included navigation is in Article I, Section 9, where Congress is forbidden from enacting any "Regulation of Commerce" that gives preference "to the Ports of one State over those of another: nor shall Vessels bound to, or from, one State, be obliged to enter, clear, or pay Duties in another., ${ }^{, 22}$ Though regulations concerning imports that might favor one port over another could be considered simply rules governing trade or exchange, laws governing the movement of vessels, the enactment of which are partially restricted by this clause, would appear to be rules concerning navigation or the transportation of articles of commerce.

In the Philadelphia convention, the extensive debate over whether "navigation acts" should require a supermajority occurred explicitly in the context of the power to regulate commerce. ${ }^{123}$ For instance, John Rutledge of South Carolina contended that "[i]t did not follow from a grant of the power to regulate trade, that it would be abused. At the worst a navigation act could bear hard a little while only on the S[outhern] States." ${ }^{124}$ The sort of navigation act contemplated here was an "act encouraging american bottoms \& seamen"125 that would incidentally raise the price of freight ${ }^{126}$ and so impact adversely exporting interests.

Moreover, there is a hint that the term "commerce" included navigation in the fact that-like "commerce and trade" - the couplet "commerce and navigation" appears, by my count, four times during the ratification debates, twice in Massachusetts and twice in Virginia." On two of these occasions, "commerce and navigation" was distinguished from "various branches of business thereon dependent" well as specifically from agriculture. ${ }^{129}$ Even expanded to include navigation or transportation, then, commerce is still distinguishable from

122 US Const Art I, \$ 9, cl 6.

123 See Farrand, ed, 2 Records of the Federal Convention at 449-53 (cited in note 119).

124 Id at 452 (statement of John Rutledge).

125 Id at 450 (statement of Gouverneur Morris).

126 See id at 451 (statement of James Madison that "the disadvantage to the S[outhern] States from a navigation act, lay chiefly in a temporary rise of freight").

127 See Elliot, ed, 3 Debates in the Several State Conventions at 428 (cited in note 100) (statement of Mr. Grayson of Virginia that "Commerce and navigation are the principal sources of" the wealth of the maritime nations of Europe); id at 604 (statement of Mr. Mason of Virginia referring to the opinion expressed by another delegate that "with respect to commerce and navigation, ... their regulation, as it now stands, was a sine qua non of the Union, and that without it the states in Convention would never concur").

128 Elliot, ed, 2 Debates in the Several State Conventions at 170 (cited in note 67) (statement of Mr. Turner of Massachusetts referring to "the deplorable state of our navigation and commerce, and various branches of business thereon dependent").

129 Id at 83 (statement of Mr. Bowdoin of Massachusetts referring to "a decrease of our commerce and navigation, and the duties and revenue arising from them. Hence an insufficient demand for the produce of our lands, and the consequent discouragement of agriculture."). 
production. If the public at the time of ratification understood the term "commerce" in the Constitution to include trade, exchange, and navigation, then that is its original meaning. ${ }^{1.00}$

On the other hand, though enactment of "navigation laws" was widely thought to be within the power of Congress, several statements suggest that such laws were considered by some at least to be distinct from regulations of commerce and that the term "navigation" was neither synonymous with nor subsumed within the term "commerce." The Virginia and North Carolina ratification conventions formally proposed that the Constitution be amended to state: "That no navigation law, or law regulating commerce, shall be passed without the consent of two thirds of the members present, in both houses." ${ }^{\text {,13 }}$ This proposed amendment both assumes that Congress has power to pass navigation laws and distinguishes such laws from regulations of commerce.

If this and other like evidence is accepted, the admitted power to pass navigation laws is most accurately conceived as an implied power that was embraced by the Necessary and Proper Clause. In which case, the congressional power to regulate transportation is proper only insofar as it is necessary to effectuate the regulation of trade and exchange between state and state. Even statements warmly supporting the enactment of navigation laws suggest that such laws were thought a necessary means to protect commerce rather than the regulation of

130 Another possibility that would bring navigation under the rubric of "commerce" would be if "commerce" referred to the trade and exchange of goods and services. Transportation would have been one of the very few, if not the only, services of that era that would operate between state and state. (Postal services might have been another, but Congress was given the power to enter this business itself by establishing post offices and post roads, US Const Art $1, \S 8, \mathrm{cl} 7$.) Services that are produced wholly within a state and then marketed or sold to citizens of other states might also be considered "commerce ... among the several States" in the same way that "commerce" includes the selling of goods that are wholly produced within a state. Under this interpretation, though Congress under the Commerce Clause could not properly regulate production of such services, like the production of goods, their marketing between states might be. I find no evidence from the records surrounding the drafting and ratification of the Constitution, however, to support this meaning. The only specific examples of commerce mentioned concern goods, in particular the produce of agriculture and manufacturing. Moreover, though the term "services" appears frequently in the records of the Philadelphia and ratification conventions, it is almost always in reference to the services of government officials and most often when discussing whether such services should be compensated. It is doubtful that, just because they were compensated, elected officials were commonly thought to be engaged in "commerce." Finally, and perhaps most persuasively, commerce is repeatedly characterized as being the activity of merchants who sell, exchange, or barter goods, not those who exchange their services for money. Both "commerce" and "merchant" have the same root, "merc," which refers to "merci" or merchandise. See 3 Oxford English Dictionary at 552 (cited in note 4); 9 Oxford English Dictionary 619 (2d ed 1989).

131 Elliot, ed, 3 Debates in the Several State Conventions at 660 (cited in note 100) (proposal of Virginia); Elliot, ed, 4 Debates in the Several State Conventions at 245 (cited in note 90) (proposal of North Carolina). See also Elliot, ed, 2 Debates in the Several State Conventions at 552-53 (cited in note 67) (same amendment disapproved by Maryland convention). 
commerce itself. As Edmund Randoph observed to the Virginia convention:

As it is the spirit of commercial nations to engross as much as possible the carrying trade, this makes it necessary to defend our commerce. But how shall we compass this end? England has arisen to the greatest height, in modern times, by her navigation act, and other excellent regulations. The same means would produce the same effects. ${ }^{1.2}$

But even this statement could be read as including navigation in the definition of "commerce."

In Gibbons, Marshall reached his conclusion that navigation was included in the term "commerce" by relying on the definition of "commerce" as "intercourse." "This was indeed the first definition of "commerce" offered in Johnson's dictionary. ${ }^{134}$ Johnson, however, defines "intercourse" as " 1 . Commerce; exchange" and " 2 . Communication: followed by with," "intercourse" (especially when not "followed by with") was itself much broader than trade and exchange. ${ }^{136}$ Moreover, it is difficult to imagine that John Marshall, much less the founders, believed that the term "commerce" in the Constitution embraced noncommercial intercourse or every form of intercourse. Though the term "intercourse" appears sixty-three times in the records of the ratification debates (sometimes with a broader meaning), on each of the six times it is used in conjunction with "commercial," it is a clear reference to foreign trade-though these examples of usage might also be broad enough to include transport for purposes of trade. ${ }^{1.37}$ And while "inter-

132 Elliot, ed, 3 Debates in the Several State Conventions at 78 (cited in note 100).

13322 US (9 Wheat) at 189-90 ("Commerce, undoubtedly, is traffic, but it is something more: it is intercourse. It describes the commercial intercourse between nations, and parts of nations, in all its branches, and is regulated by prescribing rules for carrying on that intercourse."). It is worth noting that Chief Justice Marshall did not suggest that navigation was covered because "commerce" included the trade or exchange of services for money.

134 See text accompanying note 53.

135 Johnson, 1 A Dictionary of the English Language (cited in note 53).

136 In light of the secondary meaning of "intercourse" as "communication," we might also view "commerce" as connoting the somewhat broader meaning of conveying, moving, or transporting something from one place to another - which is accomplished by trade, exchange, navigation or other means-as distinct from producing the thing to be communicated or transported. We speak of intellectual intercourse or exchange between people, which is distinct from the production of ideas that are then communicated to others, so this somewhat expanded conception of "commerce" would also preserve the distinction between commerce and agriculture and manufacturing. Though this seems a plausible conception of "commerce," apart from the definition in Johnson, I know of no evidence that supports this as either the prevalent public definition or as the specific meaning of "commerce" in the Constitution.

137 The term "commercial intercourse" is used six times by four speakers at two conven- 
course" sometimes had a broader meaning, we must never forget that the Constitution speaks of "commerce" not the "regulation of intercourse" among the states.

During the Progressive Era, the Supreme Court rejected a broad conception of commerce as embracing any gainful activity in favor of the more limited conception of commerce as "trade and exchange" that is so uniformly reflected in the surviving records of the drafting and ratification of the Constitution (though it never hesitated to sanction the power of Congress to regulate the instrumentalities of commerce as well as commerce itself). Beginning with the 1895 case of United States v E.C. Knight $\mathrm{Co}^{138}$ and up to the 1936 case of Carter $v$ Carter Coal $\mathrm{Co}^{139}$ the Court drew a distinction between "production"-such as manufacturing, agriculture, or mining-and "commerce" or trade in the things produced. As Chief Justice Fuller wrote in E.C. Knight: "Commerce succeeds to manufacture, and is not a part of it.... The fact that an article is manufactured for export to another State does not of itself make it an article of interstate commerce."140 And in Carter Coal, Justice Sutherland defined "commerce" as "the equivalent of the phrase "intercourse for the purpose of trade.", "141 "Mining" he explained, "brings the subject matter of commerce into existence. Commerce disposes of it." ${ }^{142}$ Sutherland's definition harkens back to Marshall's use of "intercourse" without the unwarranted suggestion that "commerce" embraces every form of intercourse. It also seems a reasonable definition of the term "commercial intercourse."

Using this distinction, the power of Congress to regulate the economy was sharply restricted. It is no surprise, therefore, that these decisions were roundly condemned by political and academic proponents of national control of the entire economy. ${ }^{144}$ As was to be expected, the Court was criticized for its failure to acknowledge that the

tions. See Elliot, ed, 3 Debates in the Several State Conventions at 344 (cited in note 100) (statement of Mr. Monroe of Virginia referring to "a commercial intercourse between the United States and Spain"); id at 365 (statement of Mr. Corbin of Virginia referring to treaties "being a regulation of commercial intercourse between different nations"); Elliot, ed, 4 Debates in the Several State Conventions at 119 (cited in note 90) (statement of Mr. Davie of North Carolina referring to "that commercial intercourse, which, founded on the universal protection of private property, has, in a measure, made the world one nation"); id at 221 (statement of Mr. Iredell of North Carolina that: "At the beginning of the late war with Great Britain, the Parliament thought proper to stop all commercial intercourse with the American provinces.").

138156 US 1 (holding that the Sherman Act did not apply to manufacturing trusts).

139298 US 238, 298 (1936) (ruling that Congress could not regulate the conditions under which coal is produced before it became an article of commerce).

140156 US at $12-13$.

141298 US at 298.

142 Id at 304.

143 See note 137 .

144 See, for example, Hamilton and Adair, The Power to Govern at 184-94 (cited in note 15). 
meaning of the Constitution must evolve to meet changing circumstance. ${ }^{145}$ More surprisingly, however, in light of the historical evidence presented here that strongly supports its usage, the Court was also harshly criticized for distorting the original meaning of "commerce."

\section{Academics Dispute the Original Meaning of Commerce}

In their influential little book, The Power to Govern: The Constitution-Then and Now, published in 1937, Walton Hamilton and Douglass Adair castigate the Court for imposing its conception of commerce on the founding generation in defiance of the historical understanding. "A narrowing of the concept "commerce," they confidently assert, "is at odds with [the Fathers'] contemporary usage.", But though they pick quotes from the ratification debates reflecting the demand for stronger national governance, they reveal little of the evidence of usage also to be found there ${ }^{147}$ or in the notes of the Philadelphia convention that I have summarized here. Instead, they rely primarily on five pages of quotes from a pamphlet by Tench Coxe, written before the Constitutional Convention, in which he argues for a sweeping national control over the economy and on Hamilton's 1791 Report on Manufactures, which Coxe is reputed to have helped draft.

Hamilton, it will be recalled, proposed to the Constitutional Convention a plan of government in which the legislature would have the "power to pass all laws whatsoever" ${ }^{\text {"148 }}$ subject only to a negative by the President. His plan was never considered, and a general grant of powers to the Congress was rejected by the Convention in favor of an enumeration. ${ }^{149}$ Yet for the rest of his career, Hamilton never wavered in his efforts on behalf of expanding the power of the national government. Despite this, when he wrote in The Federalist Papers, when he spoke at the New York ratification convention, and in his opinion supporting the constitutionality of a national bank, Hamilton used the word "commerce" in its ordinary narrow sense."

145 Id at 191-94.

146 Id at 181.

147 But see id at 163 (quoting William Davie's reference to "commerce, agriculture, and manufactures of America" and his assertion that "Commerce, sir, is the nurse of both" without commenting on the distinction explicit in Davie's usage).

148 Farrand, ed, 1 Records of the Federal Convention at 291 (cited in note 112).

149 The Convention rejected language proposed by Gunning Bedford of Delaware that would have given Congress power "to legislate in all Cases for the general Interests of the Union, and also in those Cases to which the States are separately incompetent, or in which the Harmony of the United States may be interrupted by the Exercise of individual Legislation." Farrand, ed, 2 Records of the Federal Convention at 131-32 (cited in note 119).

150 See text accompanying notes $61-66,75-78$. 
In 1953, this originalist criticism of the Supreme Court's definition of "commerce" during the Progressive Era was picked up and greatly expanded by William Crosskey in his massive book, Politics and the Constitution in the History of the United States. ${ }^{1.1}$ Space prevents me from considering in any detail Crosskey's indictment of the Progressive Era Court's Commerce Clause doctrines and of anyone else who disagreed with his conception of national power-especially James Madison, whom Crosskey repeatedly and without foundation accused of fabricating his notes of the debates in the Constitutional Convention. ${ }^{152}$ Like Adair and Douglass, Crosskey studiously avoids consulting the Philadelphia or state conventions for evidence of usage, focusing instead on an extensive canvass of pre-revolutionary and preConstitutional sources, such as John Dickinson's 1765 pamphlet, The Late Regulations Respecting the British Colonies Considered (which was written at a time when the plenary power of England to govern the affairs of the colonies was politically difficult to question).

I am not disputing here that "commerce" had a broad as well as a narrow meaning, or that many before and after the Constitution strongly favored a national government powerful enough to govern all "gainful activities." I only dispute, on the basis of the evidence of usage presented here and the clash of interests that existed in the country at the time, that a government of so unlimited a power was adopted in 1789. And it is striking the degree to which these authors, whose tone is nothing if not self-righteous towards those who do not share their views, completely ignore the evidence of usage that the records of the drafting and ratification process reveal.

151 See note 16.

152 See, for example, Crosskey, 1 Politics and the Constitution at 12-13 (cited in note 28) (Madison's notes "cannot be accepted as a complete and wholly truthful account of the matters they purport to record" and are "misleading."). Crosskey's baseless charges are repeated with increasing intensity throughout his study, but, though he promised to substantiate them in a later work, he never did. His assertions of fabrication have been thoroughly refuted. See Irving Brant, Mr. Crosskey and Mr. Madison, 54 Colum L Rev 443 (1954) (discussing the lack of foundation for Crosskey's claims and explaining the absurdity of Crosskey's claim that Madison forged some of his notes); Donald O. Dewey, Crosskey Versus Madison: James Madison and the United States Constitution, 19 Richmond L Rev 435 (1985) (explaining Crosskey's failure to document his claims and the evidence against the claim of Madison's forgery). It is inadvisable to read Crosskey without also reading the various reviews of his writings by those knowledgeable enough to point out his distortions and omissions.

153 Late in life Jefferson recalled his opposition to what he called "the half-way house of John Dickinson who admitted that England had a right to regulate our commerce, and to lay duties on it for the purposes of regulation, but not of raising revenue." Paul Leicester Ford, ed, 1 The Works of Thomas Jefferson 14 (Knickerbocker 1904).

154 Though I confess that my examination of the evidence of usage during the drafting and ratification of the Constitution has now made me somewhat skeptical of the contrary claim that "commerce" (as distinct from "commercial") was used more broadly outside that context. 
Even supposing these critics are right to maintain that "commerce" has a meaning as broad as any "gainful activity," however, the implications of adopting this broader meaning may be less than is commonly believed. As I shall discuss next, the reach of even a broad conception of "commerce" is confined by the meaning of the rest of the clause - that is, by the phrases "among the several States" and "To regulate." 155

\section{THE ORIGINAL MEANING OF "AMONG THE SEVERAL STATES" AND "TO REGULATE"}

A. The Meaning of "among the several States"

1. Originalist evidence.

a) The Text. Textual analysis of the Commerce Clause strongly supports a conclusion that the phrase "among the several States" refers to "between people of different states." If this phrase included commerce between people of the same state that takes place wholly within a single state, the Commerce Clause would then embrace all commerce. This interpretation would render the phrase "among the several States" superfluous. The only reason for adding "among the several States" (and with foreign nations and Indian tribes) is to $e x$ clude some type of commerce from the power of Congress. Therefore, barring some extrinsic evidence that suggests another plausible possibility, we can safely conclude that the original meaning of "among the several States" to those who used and heard this phrase in the Constitution was commerce that occurred, in Hamilton's words, "between the States." Us.56 confirms this.

b) The Federalist Papers. In Federalist 42, Madison clarifies that the purpose of the power to regulate commerce "among the several States" was to manage trade between people of different states and facilitate the essential power of regulating trade with foreign nations:

The defect of power in the existing Confederacy to regulate the commerce between its several members is in the number of those which have been clearly pointed out by experience.... [W]ithout this supplemental provision, the great and essential power of

155 Moreover, as Nelson and Pushaw discuss at length, Congress has claimed under the Commerce Clause powers far broader than even the most expansive originalist definition ever proposed. See Nelson and Pushaw, 85 Iowa L Rev at 119-72 (cited in note 11).

156 Federalist 23 (Hamilton), in Rossiter, ed, The Federalist Papers at 153 (cited in note 61) ("The principal purposes to be answered by union are these-the common defense of the members; the preservation of the public peace, as well against internal convulsions as external attacks; the regulation of commerce with other nations and between the States; the superintendence of our intercourse, political and commercial, with foreign countries."). 
regulating foreign commerce would have been incomplete and ineffectual. A very material object of this power was the relief of the States which import and export through other States from the improper contributions levied on them by the latter. Were these at liberty to regulate the trade between State and State, it must be foreseen that ways would be found out to load the articles of import and export, during the passage through their jurisdiction, with duties which would fall on the makers of the latter and the consumers of the former. ${ }^{157}$

In no way would such a power reach purely intrastate activities, whether gainful or not, a point that he emphasized again in Federalist 45:

The powers delegated by the proposed Constitution to the federal government are few and defined. Those which are to remain in the State governments are numerous and indefinite. The former will be exercised principally on external objects, as war, peace, negotiation, and foreign commerce; with which last the power of taxation will, for the most part, be connected. The powers reserved to the several States will extend to all the objects which, in the ordinary course of affairs, concern the lives, liberties, and properties of the people, and the internal order, improvement, and prosperity of the State."

Trade "between the States" was a usage that Hamilton would continue to employ when referring to the Commerce Clause while advocating, in his opinion to President Washington, that Congress had the power to incorporate a national bank. ${ }^{159}$

Both the meaning of the term and the well-known purpose of the clause were made clear by Hamilton in The Federalist Papers. Under the Articles of Confederation, the states had "fettered, interrupted and narrowed" 160 the flow of commerce from one state to another by protective legislation of all sorts. Apart from the need to negotiate treaties of commerce with other nations, the principal purpose for adopting a new Constitution was to deprive the states of the power to interfere with productive exchanges.

157 Federalist 42 (Madison), in Rossiter, ed, The Federalist Papers at 267-68 (cited in note 61) (emphases added).

158 Federalist 45 (Madison), in Rossiter, ed, The Federalist Papers at 292-93 (cited in note 61). See also id at 293 ("The regulation of commerce, it is true, is a new power; but that seems to be an addition which few oppose and from which no apprehensions are entertained.").

159 See note 66 and accompanying text.

160 Federalist 11 (Hamilton), in Rossiter, ed, The Federalist Papers at 90 (cited in note 61). 
An unrestrained intercourse between the States themselves will advance the trade of each by an interchange of their respective productions, not only for the supply of reciprocal wants at home, but for exportation to foreign markets. The veins of commerce in every part will be replenished and will acquire additional motion and vigor from a free circulation of the commodities of every part. Commercial enterprise will have much greater scope from the diversity in the productions of different States. When the staple of one fails from a bad harvest or unproductive crop, it can call to its aid the staple of another. The variety, not less than the value, of products for exportation contributes to the activity of foreign commerce. It can be conducted upon much better terms with a large number of materials of a given value than with a small number of materials of the same value, arising from the competitions of trade and from the fluctuations of markets. ${ }^{161}$

c) The ratification debates. In the New York convention, John Lansing, who had been a delegate in Philadelphia, praised the Commerce Clause and complained about " $[\mathrm{t}]$ he languishing situation of our commerce [that] has also been attributed to the impotence of Congress." ${ }^{\text {"162 }} \mathrm{He}$ then asserted that "all the states, excepting two, had passed laws to enable Congress to regulate commerce, and that those two were not indisposed to vest that power." ${ }^{163}$ Lansing was referring here to the 1784 Act of Congress asking the states for the power to regulate the trade between different states. ${ }^{164}$ In no way did this proposed act reach commerce or trade that laid solely within any state. ${ }^{165}$

Finally, the silence from the southern states during ratification supports this interpretation. It can be asserted with certainty that the southern states would never have ratified the Constitution if the power to regulate commerce among the states included the power to regulate the slave trade within a particular state, which was unquestionably and reprehensibly thought to be a form of commerce. ${ }^{166}$ In my

161 Id at 89-90 (emphasis added).

162 Elliot, ed, 2 Debates in the Several State Conventions at 218 (cited in note 67).

163 Id.

164 The Act was ineffectual because most of the states that accepted the recommendation of Congress made their consent contingent on the unanimous acceptance of all the other states. When this did not occur, the measure failed. See Report of the States on the Regulation of Commerce, \&c., (Friday, March 3, 1786), in Jonathan Elliot, ed, 1 The Debates in the Several State Conventions on the Adoption of the Federal Constitution 108-11 (Taylor \& Maury 2d ed 1863).

165 In fact, the Act appears to have focused entirely on foreign commerce. See id at 106-08.

166 See Scott v Sandford ("Dred Scott"), 60 US 393, 408 (1858) (describing the English government as "extensively engaged in this commerce"). See also id at 425 (describing slaves as "subjects of commerce"). See also text accompanying notes 199-202 (discussing the relationship between the Commerce Clause and the restriction on Congress's power to restrict the slave 
view, asking whether a particular meaning would have been agreed to by one group or another is not the best indication of the original meaning of any constitutional provision. At issue should be the public meaning of the term to which they did agree. Nonetheless, when supported by other types of evidence of original meaning, the fact that the slave trade was considered outside the power of Congress to regulate commerce "among the several States" bolsters our understanding of that phrase's public meaning.

d) Other commentators. Although this interpretation of "among the states" has been contested, most vigorously by William Crosskey," there remains a scholarly and judicial consensus in favor of this as the original meaning. ${ }^{168}$ Consistent with the scheme of federalism that motivated the granting of a power to regulate commerce among the states to Congress, trade that occurs wholly within a state was not commerce "among the states" and, therefore, the regulation of such commerce was not among the powers of Congress. As professor and jurist St. George Tucker, one of the earliest scholarly expositors on the Constitution, explained: "The constitution of the United States does not authorise congress to regulate, or in any manner to interfere with, the domestic commerce of any state." of such intrastate commerce, "a vessel wholly employed in that domestic commerce, seems not to be subject to the control of the laws of the United States." ${ }^{170}$ Tucker allowed that federal law could punish or seize the vessels of persons who gave "aid or assistance to any fraudulent commerce, either with foreign parts, or between the states." "may also prescribe, or limit the terms and conditions, upon which vessels may be permitted to trade with foreign parts, or with other states." ${ }^{172}$ But, citing the Tenth Amendment, Tucker concluded that Congress, under its power to regulate commerce among the states, has

trade with other nations).

167 See Crosskey, 1 Politics and the Constitution at 50-83 (cited in note 28) (noting the difference between "among" and "between" and asserting that the natural meaning of "among the several states" included all commerce occurring within any state).

168 See, for example, Nelson and Pushaw, 85 lowa L Rev at 42-49 (cited in note 11) (discussing deficiencies in Crosskey's interpretation of "among the States" and concluding: "Although Crosskey's interpretation is defensible, he did not marshal evidence strong enough to overcome the presumption that the regulation of commerce, like all federal power, does not extend purely to internal state affairs.").

169 St. George Tucker, Appendix, in 1 William Blackstone, Commentaries: With Notes of Reference to the Constitution and Laws of the Federal Government of the United States and of the Commonwealth of Virginia 250, $\mathrm{n}$ * (William Young Birch and Abraham Small 1803).

170 Id. Notice once again the close connection between "commerce" and navigation.

171 Id.

172 Id. By referring to a navigation law that limits "the terms and conditions, upon which vessels may be permitted to trade," Tucker's usage again suggests that navigation is subsumed within the meaning of trade or commerce. Id. 
"no constitutional right to control the intercourse between any two or more parts of the same state.",173

2. The original meaning of "among the states" independently limits the federal commerce power.

Adopting the narrower meaning of "among the several States" also reduces the significance of whether "commerce" is interpreted broadly to include any gainful activity or limited only to trade or exchange. For if Congress can only regulate gainful activity that takes place between people of different states, even the broader definition of commerce will not encompass much more than trade or exchange.

Thus, supposing the Progressive Era courts were wrong to exclude manufacturing, agriculture, and mining from the category of "commerce," they were on to something nonetheless. It is hard even to imagine either a good being manufactured or a crop being grown "among the states" or "between state and state" unless the factory or farm physically straddles a state line. Of course, when a company that manufactures goods or raises crops then sells them or transports them for gain from one state to another, this aspect of its operation is commerce "among the states" under even the narrow definition of commerce and is subject to federal regulation. Thus, ordinarily, manufacturing, agriculture, and mining-even when "commercial" in the broadest sense-do not occur between states and therefore are outside the regulatory powers of Congress.

I say "ordinarily" because one can imagine industrial, agricultural, or mining processes which, though otherwise within a state, extend beyond that state by emitting harmful substances into the air or water that are carried into neighboring states, like one can imagine a person standing in Indiana and shooting a bullet into Illinois. Therefore, just as the regulation of a shipment of products to other states is "proper" under the Commerce Clause, the "commercial" production of harmful emissions that cross state lines would be included under the broader definition of "commerce." Of course, the fact that one aspect of a business is subject to regulation does not then mean that all its activities are then appropriately regulated. Only commerce that occurs "among the several States" is subject to congressional regulation. In such cases, then, adopting a conception of "commerce" as including all "gainful activity" would be significant even though manufacturing, agriculture, and mining usually occur within a single state. 
3. Commerce "concerning more than one state" is too broad a construction of the original meaning of "among the several States."

While properly rejecting Crosskey's claim that the Commerce Clause gives Congress the power to regulate any commerce anywhere in the United States, ${ }^{174}$ Nelson and Pushaw unfortunately accept Chief Justice Marshall's contention that this phrase means "concerns more states than one" courts ever since. ${ }^{176}$ Thus they contend that under the Commerce Clause, Congress may regulate not only "commerce that actually moves 'between' the states" but also commerce "that occurs within a state and has external effects." the sources that clearly spoke of commerce as "between state and state."

The Commerce Clause grants Congress the power to regulate commerce that occurs "among the several States," which we have seen meant "between state and state" or between persons in one state and persons in another. It does not speak of a power to regulate commerce that "concerns" more than one state, or even commerce between persons of the same state that somehow "concerns" other states. By the same token, the Commerce Clause also empowers Congress to regulate commerce "with foreign Nations, ... and with the Indian Tribes." It does not empower Congress to regulate commerce that concerns or affects foreign nations or that concerns or affects Indian tribes. ${ }^{180}$

Marshall's vague formulation has improperly permitted the expansion of the power to regulate commerce beyond that which actually crosses state lines. The interpretive issue at this juncture is not whether it might be "necessary and proper" to regulate either noncommercial actions or entirely intrastate commerce that has a direct

174 Nelson and Pushaw, 85 Iowa L Rev at 43 (cited in note 11) ("[I]f the drafters had intended to cover 'all commerce,' they could have said so simply.").

175 Gibbons, 22 US ( 9 Wheat) at 194-95.

176 See, for example, Lopez, 514 US at 553 (citing Gibbons).

177 Nelson and Pushaw, 85 lowa L Rev at 42 (cited in note 11).

178 They rely on a number of secondary sources-including, curiously, Crosskey, whose interpretation they otherwise reject - who argues that "among" had a broader meaning. See id. This evidence is insufficient, however, to establish that the appearance of "among" in the Commerce Clause refers to something other than commerce that takes place "between state and state," and Nelson and Pushaw offer no new evidence that bears directly on this question.

179 US Const Art $1, \S 8, \mathrm{cl} 3$.

180 This is not to deny Richard Epstein's contention that all commerce takes place in one state or another. See Epstein, $73 \mathrm{Va} \mathrm{L} \mathrm{Rev} \mathrm{at} 1403$ (cited in note 19). Rather, it is to insist that Congress has power only to regulate those activities that are part of a transaction between persons of different states (or with foreign nations or Indian tribes), not a transaction between persons of the same state. 
impact upon commerce that does cross state lines. The issue here is whether Congress's power under the Commerce Clause extends to commerce that occurs wholly within one state but still can be said to "concern" more states than one. The original meaning of "among the several States" provides no warrant for this extension of power.

Determining whether a particular regulation of activity that is not "commerce ... among the several States"-that is, trade between state and state -is constitutional requires an assessment not only of the Commerce Clause but of the Necessary and Proper Clause as well. This is not the place to discuss fully the original meaning of the Necessary and Proper Clause. ${ }^{181}$ Suffice it to say that the requirement of "necessity" requires a showing, not merely an assertion, of means-end fit, while "propriety" requires a showing that the exercise of power lies properly within the jurisdiction of Congress. As summarized by Gary Lawson and Patricia Granger:

In view of the limited character of the national government under the Constitution, Congress's choice of means to execute federal powers would be constrained in at least three ways: first, an executory law would have to conform to the "proper" allocation of authority within the federal government; second, such a law would have to be within the "proper" scope of the federal government's limited jurisdiction with respect to the retained prerogatives of the states; and third, the law would have to be within the "proper" scope of the federal government's limited jurisdiction with respect to the people's retained rights. In other words,

181 I began this inquiry in Randy E. Barnett, Necessary and Proper, 44 UCLA L Rev 745 (1997) (distinguishing the Madisonian from Marshallian conceptions of necessity). Since that article was published I have come to think that the two sides of this controversy were not as far apart as is commonly believed. On one side, Madison rejected a conception of necessity as "indispensably necessary" as too confining. See Elliot, ed, 4 Debates in the Several State Conventions at 417 (cited in note 90) (statement of Rep. Madison to House of Representatives, February 2, 1791) (urging a "liberal construction" since "very few acts of the legislature could be proved essentially necessary to the absolute existence of government"). While Hamilton, in turn, argued that some degree of means-end fit must be shown. See Hamilton, Opinion on Bank at 104 (cited in note 66) ("The relation between the measure and the end; between the nature of the mean employed towards the execution of a power and the object of that power must be the criterion of constitutionality not the more or less of necessity or utility."). Even John Marshall's opinion in McCulloch v Maryland, 17 US (4 Wheat) 316 (1819), however, does not necessarily give Congress a blank check to assess the necessity and propriety of its own acts. See David P. Currie, The Constitution in the Supreme Court: State and Congressional Powers, 1801-35, 49 U Chi L Rev 931, 932 (1982) ("In light of earlier statements in [Marshall's] opinion, the implication seems unmistakable: incidental authority must not be so broadly construed as to subvert the basic principle that Congress has limited powers."). What most divided them was a combination of (a) the degree of means-end fit that must be shown, (b) whether the bank met the requisite degree of fit, and (c) the degree of judicial deference that was appropriate. I will present this evidence at greater length in The Presumption of Liberty: Natural Rights and the Constitution. 
... executory laws must be consistent with principles of separation of powers, principles of federalism, and individual rights. ${ }^{18}$

My objective in this Article is not to define precisely the incidental powers of Congress under the Necessary and Proper Clause to reach activity that is not commerce, or is commerce that is not between state and state. My goal is only to define as precisely as the evidence permits the original meaning of "commerce," "among the several States," and "To regulate" in the face of judicial and academic disagreement about the meaning of these terms. For knowing the scope of these terms is the first essential step towards determining if some other power is really incidental to and for the purpose of the regulation of commerce among the states.

\section{B. The Meaning of "To regulate"}

1. The power to regulate does not generally include the power to prohibit.

Samuel Johnson defines "to regulate" as " 1 . To adjust by rule or method. . . . 2. To direct." ${ }^{183}$ In other words, the term "to regulate" means "to make regular." The power to regulate is, in essence, the power to say, "if you want to do something, here is how you must do it." For example, the making of contracts and wills are "regulated" by the law of contracts and estates. To make an enforceable agreement for a sale of goods over five hundred dollars requires that the agreement be in writing. To make a will requires a specified number of witnesses to one's signature. These requirements regulate-or "make regular"- the making of contracts and wills by subjecting them to a rule or method. The power to regulate the making of contracts or wills is not the power to prohibit such activity, even though contracts or wills that do not conform to the regulation are necessarily unenforceable. A pure regulation of commerce, then, is a set of rules that tells people, "If you want to trade or exchange with others, here is how you must go about it."

In contrast, Johnson defines "to prohibit" as " 1 . To forbid; to interdict by authority. ...2. To debar; to hinder." ing, and hindering are not the same thing as regulating, or "making regular," or adjusting by rule or method. It does not tell you how to do

182 Gary Lawson and Patricia B. Granger, The "Proper" Scope of Federal Power: A Jurisdictional Interpretation of the Sweeping Clause, 43 Duke L J 267, 297 (1993) (arguing that a jurisdictional approach to the Sweeping Clause best fits the text and the understanding of early legal scholars).

183 Johnson, 2 A Dictionary of the English Language (cited in note 54).

184 Id. 
something, but instead tells you that you may not do it at all. And in Johnson's dictionary, neither "to regulate" nor "to prohibit" is defined in terms of the other; each seems quite distinct. Indeed, both terms appear in the Constitution and the context in which they are used suggests that their meanings sharply differ.

Apart from the Commerce Clause, the terms "regulate" or "regulation" appear seven other times in the body of the Constitution and three times in the amendments proposed by Congress to the states, though only once in the Bill of Rights as ratified. The term "prohibit" is used once in the body of the Constitution and twice in the Bill of Rights. Article I, Section 4 gives Congress the power to "alter such Regulations" ${ }^{\prime 185}$ on the time, place, and manner of elections prescribed by state legislatures. Clearly, the power to regulate or facilitate elections is not the power to prohibit them. Article I, Section 8 gives Congress the power " $[\mathrm{t}] \mathrm{o}$... regulate the Value" the use of money or to "regulate" its value to zero.

In two places the Constitution makes an explicit distinction between prohibition and regulation. Article III, Section 2 gives the Supreme Court appellate jurisdiction, both as to law and fact, "with such Exceptions, and under such Regulations as the Congress shall make." stitution distinguished Congress's power to regulate or subject to rule the Court's appellate jurisdiction and its power to prohibit the Court from exercising its jurisdiction by making "exceptions" thereto. If the power to make regulations included the power to prohibit that which is regulated, there would have been no need to give explicit power to Congress to make "exceptions" to appellate jurisdiction.

That the Constitution does not adopt the broader meaning of regulation as "to govern" is also reflected in Article I, Section 8, which gives Congress the power " $[\mathrm{t}] \mathrm{o}$ make Rules for the Government and Regulation of the land and naval Forces." ment" is coupled with "regulation" in a manner that makes clear that Congress has complete power to command or govern the army and navy, not merely the power to regulate them.

Less clear, but still consistent with the distinction between "To regulate" and "to govern," is Congress's power in Article IV, Section 3 "to dispose of and make all needful Rules and Regulations respecting the Territory or other Property belonging to the United States."

185 US Const Art I, $\$ 4, \mathrm{cl} 1$.

186 US Const Art I, $\$ 8, \mathrm{cl} 5$ (emphasis added).

187 US Const Art III, $\$ 2$, cl 2.

188 US Const Art I, \& 8, cl 14.

189 US Const Art IV, $\$ 3, \mathrm{cl} 12$. 
Congress clearly has the power to govern the territories, and the term "rules and regulations" suggests strongly that its powers are broader than merely regulatory, though it includes the power to make "regulations" as well as other needful "rules."

That the Constitution uses the term "to regulate" in this sense is made plain by the Second Amendment, the first portion of which reads, "A well-regulated Militia, being necessary to the security of a free State." "A "well-regulated" militia is not a prohibited militia but one that is well drilled. ${ }^{191}$ Even those who read the Second Amendment as a "collective" rather than an individual right on the basis of this preface concede-indeed their theory requires them to insistthat the power to regulate the militia that the Constitution elsewhere confers upon Congress $^{192}$ does not include the power to forbid or prohibit the militia. By their interpretation, the sole purpose of the Second Amendment was to protect the continued existence of the state militias. ${ }^{193}$ By the same token, the power of Congress to "well-regulate" commerce among the states does not include the power to forbid or prohibit commerce. ${ }^{144}$ James Madison described a direct parallel between the regulation of the militia and the regulation of commerce when he asked:

How can the trade between the different States be duly regulated without some knowledge of their relative situations in these and other points? ... How can uniform regulations for the militia be duly provided without a similar knowledge of some internal cir-

190 US Const Amend II.

191 This is implicit in Hamilton's observation that:

To oblige the great body of the yeomanry and of the other classes of the citizens to be under arms for the purpose of going through military exercises and evolutions, as often as might be necessary to acquire the degree of perfection which would entitle them to the character of a well-regulated militia, would be a real grievance to the people and a serious public inconvenience and loss.

Federalist 29 (Hamilton), in Rossiter, ed, The Federalist Papers at 184 (cited in note 61).

192 See US Const Art I, \& 8, cl 16 (referring to the power of Congress: "To provide for organizing, arming, and disciplining, the Militia, and for governing such Part of them as may be employed in the Service of the United States."). Even here the distinction between regulation and governance is implicit. Congress has the general power to regulate the militia by "organizing, arming, and disciplining" it (but not the power to abolish it), and has the stronger power "to govern" only that "part" of the militia that is in actual service.

193 See, for example, Keith A. Ehrman and Dennis A. Henigan, The Second Amendment in the Twentieth Century: Have You Seen Your Militia Lately?, 15 U Dayton L Rev 5, 57 (1989) (arguing that the framers' intent behind the Second Amendment was to protect independent state militias).

194 The First Amendment originally proposed by Congress that was never ratified, though less clear, is entirely consistent with the meaning of regulate for which I am contending. It directs that the number of representatives "shall be so regulated by Congress" that the number of Representatives shall not fall below a specified proportion of the population. 
cumstances by which the States are distinguished from each other? These are the principal objects of federal legislation and suggest most forcibly the extensive information which the representatives ought to acquire. ${ }^{195}$

How do the debates in the state ratification debates bear out this distinction between the power "to regulate" and the power "to prohibit"? The term "regulate" appears fifty-five times in all the records we have of the deliberations in the states. ${ }^{19 \%}$ In every case where the context makes the meaning clear, the term connotes "subject to a rule" or "make regular" in the sense that "if you want to do something, here is how you should do it." As with the word "commerce," the term "regulate" is used with stunning uniformity-so much so that it would be tedious to reproduce the quotes here. And it is unnecessary because the term appears overwhelmingly in the context of regulatory powers that, as we observed in the intratextual discussion above, could not plausibly have included the power to prohibit such activities. These are references to the powers to regulate elections (18), jury trials (6), courts (5), militias (2), taxes (1), treaties (1), and the deliberations of the Senate (1). ${ }^{197}$ In the rest, the term "regulate" is used in its ordinary sense, in some context other than the Constitution of the new government. $^{198}$

195 Federalist 53 (Madison), in Rossiter, ed, The Federalist Papers at 333 (cited in note 61). Notice here the reference to the Commerce Clause as regulating "trade between the different States." In Federalist 4, John Jay drew a like parallel between the power of Congress over the militia and commerce when he referred to "our trade prudently regulated, our militia properly organized and disciplined." Federalist 4 (Jay), in Rossiter, ed, The Federalist Papers at 49 (cited in note 61 ).

196 Massachusetts (13), Connecticut (1), New York (9), Pennsylvania (2), Virginia (16), North Carolina (11), and South Carolina (3).

197 I have, of course, omitted from this list discussions of the power to regulate commerce (5), trade (2), or contracts (1) since it is the scope of this power that is at issue here. Nevertheless the two references to regulating "trade" support the narrow meaning of "commerce."

198 See, for example, Elliot, ed, 2 Debates in the Several State Conventions at 16 (cited in note 67) ("[W]e ought to consult the sentiments of wise men, who have written on the subject of government, and thereby regulate our decision on this business."); id at 252 ("[T]he general sense of the people will regulate the conduct of their representatives."); id at 301 ("[T]here should be, in every republic, some permanent body to correct the prejudices, check the intemperate passions, and regulate the fluctuations, of a popular assembly."); id at 384 (referring to "making laws to regulate the height of fences and the repairing of roads"); Elliot, ed, 3 Debates in the Several State Conventions at 137 (cited in note 100) ("There are certain maxims by which every wise and enlightened people will regulate their conduct."); id at 227 ("We may now regulate and frame a plan that will enable us to repel attacks."). 
2. The power "to regulate" might sometimes include the power "to prohibit."

There is, however, one now-obsolete passage of the Constitution that argues for a broader original meaning of the term "To regulate." Article I, Section 9, stipulates that the "Migration or Importation of such Persons as any of the States now existing shall think proper to admit, shall not be prohibited by the Congress prior to the Year" ${ }^{\text {"199 }}$ 1808. This suggests that, but for this Section, Congress would have the power to prohibit the slave trade with foreign nations as part of either its taxing power or its power to regulate commerce.

Edmund Randolph discussed this clause as part of his argument to the Virginia ratification convention that the exceptions to Congressional powers that appeared in the Constitution in no way implied a power to legislate generally. To rebut the contrary suggestion, Randolph endeavored to show how every exception modified an enumerated power: "To what power in the general government is the exception made respecting the importation of negroes? Not from a general power, but from a particular power expressly enumerated. This is an exception from the power given them of regulating commerce. ${ }^{200}$ In this way, Randolph explicitly linked the power to prohibit the slave trade to the commerce power. Randolph's recollection is borne out by the draft sketch of a constitution he had submitted during the Convention to the Committee of Detail. In his sketch, the prohibition is listed explicitly as the second exception to the power to regulate commerce.

Ironically, just as the South's commitment to slavery undermines the inference that Congress had the power to regulate intrastate trade, thereby supporting the narrow meaning of "among the states," here the slavery issue provides evidence that Congress's power "To regulate" commerce with foreign nations was broad enough to include the power to prohibit at least some kinds of commerce. ${ }^{202}$ But this is not the only reason to believe that the power to regulate commerce included the power to prohibit at least some types of trading. Perhaps

199 US Const Art I, $\$ 9$, cl 1.

200 Elliot, ed, 3 Debates in the Several State Conventions at 464 (cited in note 100).

201 See James H. Hutson, ed, Supplement to Max Farrand's The Records of the Federal Convention of 1787187 (Yale 1987).

202 The Supreme Court later held that although the foreign slave trade was subject to congressional legislation, see Groves $v$ Slaughter, 40 US 449 (1841), the federal government clearly lacked the power to regulate the domestic slave trade. See id at 508 (Taney concurring) (" $[T]$ he power over this subject is exclusively with the several states."); id at 514 (Baldwin concurring) (asserting that the regulation of slavery "depended on the law of each state," and that "no power [over this] is granted of the Constitution to Congress"). 
the most important reason to grant Congress the power to regulate commerce was not the power to eliminate trade barriers among the several states (which Madison referred to as a "supplemental provision" ${ }^{\text {"203 }}$ ), but the power to place restrictions on foreign access to American markets to facilitate the opening of European trade to Americans as well as to promote domestic production. Thus, it was envisioned that the power to regulate trade with foreign nations included the power to prohibit certain types of trade by means of, for example, tariffs. ${ }^{204}$

However, even if it is conceded that the original meaning of "To regulate" included a power to restrict foreign commerce in negotiating treaties to lower foreign barriers to American goods as well as to protect some domestic markets from foreign competition, this aspect of the power to regulate does not necessarily extend to domestic commerce. The Constitution expressly bars Congress from using any "Regulation of Commerce" to favor the ports of one state over those of another, ${ }^{205}$ and it mandates that "all Duties, Imposts and Excises shall be uniform throughout the United States." ${ }^{206}$ These provisions deny Congress the same degree of regulatory power over domestic commerce that it has over commerce with foreign nations. And they provide circumstantial textual evidence that the domestic portion of the Commerce Clause lacked the prohibitory aspect that was included in the power to regulate commerce with foreign nations and was instead intended to eliminate and prevent any state-imposed barriers to trade between the states.

203 Federalist 42 (Madison) in Rossiter, ed, The Federalist Papers at 267-68 (cited in note 61). For the passage in which this reference appears, see text accompanying note 157.

204 Another means to promote American trade by requiring that trade be carried in American ships could be viewed as a regulation rather than a prohibition, as it states, "if you want to trade with the U.S., here is how you must do it."

205 US Const Art I, $\S 9$, cl 6. While this power applies to both domestic and foreign commerce, it does not prevent the Congress from enacting "regulations of commerce" that give preference to trade with one foreign nation over that with another.

206 US Const Art I, $\S 8$, cl 1. To the extent that duties and imposts are proper means for regulating commerce with foreign nations (as opposed to raising revenues) by favoring one nation over another or one type of good over another, this clause operates to prohibit Congress from using its power to regulate commerce among the states to impose duties or imposts to favor one state over another.

207 When the known purposes of the founders suggest that a single use of a word has two different meanings depending on the noun to which it refers, is this consistent with the objective approach to original meaning that was described above? Yes. In contracts, objective ambiguity can occur when a word has more than one reasonable or public meaning. For example, each party can use the name "Peerless" to refer to one of two different ships bearing the same name. See Raffles $v$ Wichelhaus, $2 \mathrm{H} \& \mathrm{C}$ 906, 159 Eng Rep 375 (Ex 1864). If the name "Peerless" reasonably describes both ships, then the parties' use of the term "Peerless" is ambiguous from an objective standpoint. Due to the objective ambiguity, though they used the same word, as Oliver Wendell Holmes, Jr. put it, “[each party] said a different thing.” Oliver Wendell Holmes, Jr., The 
This is precisely the distinction offered by James Madison. In correspondence with Joseph Carrington Cabell long after ratification, Madison contended that the "meaning of the power to regulate commerce is to be sought in the general use of the phrase; in other words, in the objects generally understood to be embraced by the power when it was inserted in the Constitution., ${ }^{209}$ And, as is well known, the purposes of granting Congress the power to regulate trade "with foreign nations" differed markedly from the purpose for regulating trade "among the several States." Given the need for a broader power over the former, Madison said he "always foresaw" ${ }^{210}$ difficulty properly interpreting the latter.

Being in the same terms with the power over foreign commerce, the same extent, if taken literally, would belong to it. Yet it is very certain that it grew out of the abuse of the power by the importing States in taxing the non-importing, and was intended as a negative and preventive provision against injustice among the States themselves, rather than as a power to be used for the positive purposes of the General Government, in which alone, however, the remedial power could be lodged. And it will be safer to leave the power with this key to it, than to extend to it all the qualities and incidental means belonging to the power over foreign commerce, as is unavoidable. ${ }^{211}$

In other words, the use of tariffs and other forms of "prohibitory regulation $[\mathrm{s}],{ }^{, 212}-$ the term itself a concession to the normal meaning of "regulation"-while necessary to effectuate the purposes of the

Common Law 242 (M. Howe, ed) (Belknap 1967). Likewise, a group of persons can use a single ambiguous verb to signify objectively two different activities depending on the noun to which it refers. When two people attach different meanings to the same word in a contract, we consider this to be a "misunderstanding" and assent can fail. But when a group of people agrees to use one word to connote, depending on the circumstances, two different meanings, they have objectively manifested their intentions, albeit in an awkward manner that makes the objective meaning of their words sometimes difficult to discern.

208 Cabell was a post-revolutionary intellectual and cofounder, with Thomas Jefferson, of the University of Virginia.

209 James Madison, Letter to Joseph C. Cabell (March 22, 1827), in Galliard Hunt, ed, 3 Letters and Other Writings of James Madison 571 (J.B. Lippincott 1865)

210 James Madison, Letter to Joseph C. Cabell (February 13, 1829), in Galliard Hunt, ed, 4 Letters and Other Writings of James Madison 14 (J.B. Lippincott 1865).

211 Id at 15. Madison's account would also explain why "[n]o serious and sustained effort ... was ever made to employ against the domestic slave trade the power of Congress to regulate interstate commerce." Arthur Bestor, The American Civil War as a Constitutional Crisis, 69 Am Hist Rev 327, 342 (1964). According to Bestor, "Ip]ublic opinion seems to have accepted as virtually axiomatic the constitutional principle" that Congress had no power to prohibit or obstruct the trade in slaves between the slaveholding states. Id.

212 James Madison, Letter to Joseph C. Cabell (March 22, 1827), in Hunt, ed, 3 Letters and Other Writings of James Madison at 572 (cited in note 209). 
power to regulate commerce with foreign nations, would fly in the face of the purpose for regulating commerce among the states. ${ }^{213}$ The former power was supposed to protect and promote domestic economic activities by restricting imports, as well as to levy the types of restrictions that would induce foreign nations to open their markets to American shipping and goods. By contrast, within the United States, the purpose of the power was the reverse: to eliminate trade barriers at the state level that were thought entirely proper at the national level. And this last purpose is manifested in the textual prohibitions of preferential regulations of commerce and nonuniform duties or imposts-textual provisions that support an inference that the original meaning of "To regulate" varied with the subject of the regulation.

\section{CONCLUSION}

The most persuasive evidence of original meaning-statements made during the drafting and ratification of the Constitution as well as dictionary definitions and The Federalist Papers-strongly supports Justice Thomas's and the Progressive Era Supreme Court's narrow interpretation of Congress's power "To regulate Commerce with foreign Nations, and among the several States, and with the Indian Tribes." "Commerce" means the trade or exchange of goods (including the means of transporting them); "among the several States" means between persons of one state and another; and the term "To regulate" means "to make regular" - that is, to specify how an activity may be transacted - when applied to domestic commerce, but also includes the power to make "prohibitory regulations" when applied to foreign trade. In sum, Congress has power to specify rules to govern the manner by which people may exchange or trade goods from one state to another, to remove obstructions to domestic trade erected by states, and to both regulate and restrict the flow of goods to and from other nations (and the Indian tribes) for the purpose of promoting the domestic economy and foreign trade.

To determine the constitutionality of any particular legislation and evaluate judicial applications of the Commerce Clause, however,

213 It may be argued that admitting evidence of such purposes is a reversion to original intent rather than original meaning. I discuss this evidence, however, simply to put in perspective the express textual restriction on Congress's power to restrict the slave trade with foreign nations, see US Const Art I, $\S 9$, and its possible effect on the meaning of "to regulate" in the Commerce Clause. But the same evidence of purpose that helps explain this broadening of the power "to regulate" also includes evidence that this broadening was limited to foreign trade. This is simply an example of how evidence of publicly known purposes helps to shape the original public meaning of words and phrases.

214 US Const Art I, \& 8, cl 3. 
we must also consider the meaning of the Necessary and Proper Clause. If the original meaning of "proper" in this clause was, as Gary Lawson and Patricia Granger have shown, ${ }^{215}$ that the end or purpose of a law must be within the jurisdiction of Congress to enact, a narrow conception of the Commerce Clause limits Congress to the end or purpose of making regular the trade between the states. Legislation that is actually for a different purpose cannot be upheld as "proper." As Chief Justice John Marshall stated in McCulloch $v$ Maryland, "should Congress, under the pretext of executing its powers, pass laws for the accomplishment of objects not entrusted to the government, it would become the painful duty of this tribunal ... to say that such an act was not the law of the land.",217

And, as I have argued elsewhere, ${ }^{218}$ if the Necessary and Proper Clause requires an assessment of "necessity" in which legislation is scrutinized to determine if there is adequate fit between means and ends, then the Congress must show, at minimum, it has chosen means that actually conduce to an enumerated end. Even John Marshall, who construed the degree of necessity required by the clause more loosely than I think is warranted, allowed that the means chosen must be "plainly adapted" to a "legitimate" end that is "within the scope of the constitution." "In which case, the only "appropriate means" that are actually incidental to making regular trade between the states.

This all assumes, of course, that a court is bound by the original meaning of the Commerce Clause. I have argued elsewhere why it should be, so long as it professes a commitment to a written constitution. ${ }^{221}$ Moreover in recent years there has been a marked movement on the part of constitutional theorists in the direction of original meaning, at least to provide the starting point of constitutional analysis $^{22}$-in which case, the content of the starting point surely matters. But this is an argument for another place. What has been established here is that those who have claimed that the original meaning of the Commerce Clause was narrow are right and their critics are wrong.

215 See Lawson and Granger, The "Proper" Scope of Federal Power, 43 Duke L J 267 (cited in note 182 ).

21617 US (4 Wheat) 316,316 (1819).

217 Id at 423.

218 See Barnett, Necessary and Proper, 44 UCLA L Rev at 745 (cited in note 181).

21917 US (4 Wheat) at 421 ("Let the end be legitimate, let it be within the scope of the constitution, and all means which are appropriate, which are plainly adapted to that end, which are not prohibited, but consist with the letter and spirit of the constitution, are constitutional."). See my discussion of Marshall's and Hamilton's view of "necessity" in note 181.

22017 US (4 Wheat) at 421.

221 See Barnett, 45 Loyola L Rev at 629-43 (cited in note 30) (discussing "writtenness" and the relevance of original meaning to constitutional legitimacy).

222 See id at 611-20 (describing the pervasiveness of originalism in constitutional scholarship). 


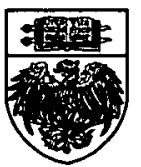

